\title{
Chemokine Signaling Controls Integrity of Radial Glial Scaffold in Developing Spinal Cord and Consequential Proper Position of Boundary Cap Cells
}

\author{
Yan Zhu, ${ }^{1}$ Tomoko Matsumoto, ${ }^{1}$ Takashi Nagasawa, ${ }^{2}$ Fabienne Mackay, ${ }^{3}$ and Fujio Murakami ${ }^{1}$ \\ ${ }^{1}$ Graduate School of Frontier Biosciences, Osaka University, Suita, Osaka 565-0871, Japan, ${ }^{2}$ Department of Immunobiology and Hematology, Institute for \\ Frontier Medical Sciences, Kyoto University, Sakyo-ku, Kyoto 606-8507, Japan, and ${ }^{3}$ Department of Immunology, Monash University, Central Clinical \\ School, Alfred Medical Research and Education Precinct, Melbourne, Victoria 3004, Australia
}

Radial glial cells are the neural progenitors of the developing CNS and have long radial processes that guide radially migrating neurons. The integrity of the radial glial scaffold, in particular proper adhesion between the endfeet of radial processes and the pial basement membrane (BM), is important for the cellular organization of the CNS, as indicated by evidence emerging from the developing cortex. However, the mechanisms underlying the maintenance of radial glial scaffold integrity during development, when the neuroepithelium rapidly expands, are still poorly understood. Here, we addressed this issue in the developing mouse spinal cord. We show that CXCR4, a receptor of chemokine CXCL12, is expressed in spinal cord radial glia. Conditional knock-out of Cxcr4 in radial glia caused disrupted radial glial scaffold with gaps at the pial endfeet layer and consequentially led to an invasion of boundary cap (BC) cells into the spinal cord. Because BC cells are PNS cells normally positioned at the incoming and outgoing axonal roots, their invasion into the spinal cord suggests a compromised CNS/PNS boundary in the absence of CXCL12/CXCR4 signaling. Both disrupted radial glial scaffold and invasion of BC cells into the CNS were also present in mice deficient in CXCR7, a second receptor of CXCL12. We further show that CXCL12 signaling promotes the radial glia adhesion to BM components and activates integrin $\beta 1$ avidity. Our study unravels a novel molecular mechanism that deploys CXCL12/CXCR4/CXCR7 for the maintenance of radial glial scaffold integrity, which in turn safeguards the CNS/PNS boundary during spinal cord development.

Key words: boundary cap cells; CXCL12; CXCR4; integrin b1; pial endfeet; radial glia

\section{Introduction}

Radial glial cells are crucial for the making of the vertebrate CNS, serving indispensable dual roles as neural progenitors and physical guides for radially migrating neurons. They exhibit radial morphology with long basal processes extending from cell somas in the ventricular zone (VZ) all the way to the pial surfaces of the neuroepithelium and contact the pial basement membrane (BM) via cone-shaped endfeet (Rakic, 1972; Misson et al., 1988; McDermott et al., 2005). Recently, it was suggested in the developing

\footnotetext{
Received Jan. 13, 2015; revised April 21, 2015; accepted May 10, 2015.

Author contributions: Y.Z. designed research; Y.Z., T.M., T.N., and F. MacKay performed research; Y.Z. and F. Murakami analyzed data; Y.Z. and F. Murakami wrote the paper.

This work was supported by the Ministry of Education, Culture, Science and Technology, Japan (Grant-in-Aid for Scientific Research 23570226 to Y.Z. and 2222004 to F. Murakami). We thank Ryoichiro Kageyama for NestinCreER ${ }^{\text {T2 }}$ transgenic mice; Toshio Ohshima for Wnt1-Cre mice; Corrinne Lobe for Z/EG transgenic mice; David Wilkinson for Krox20 in situ plasmid; Michael Wegner for Sox10 in situ plasmid; Yasunori Arimatsu for Nestin antibody; Hiroaki Kobayashi, Kazuhiko Nishida, and Peter Karagiannis for their critical reading of this manuscript; and Xun Hong, who was supported by Osaka University Program for the Support of Networking among Present and Future Researchers, for technical support.

The authors declare no competing financial interests.

Correspondence should be addressed to Yan Zhu at his present address: Division of Brain Function, National Institute of Genetics, Department of Genetics, Sokendai, Yata 1111, Mishima 411-8540, Japan. E-mail: yan-zhu@umin.ac.jp.

DOI:10.1523/JNEUROSCI.0156-15.2015

Copyright $\odot 2015$ the authors $\quad 0270-6474 / 15 / 359211-14 \$ 15.00 / 0$
}

cortex that an integral radial glial scaffold with proper adhesion of radial endfeet to the pial BM is crucial for the cortical cellular organization. Weakening this adhesion in mutants, either by targeting adhesive molecules or their downstream signaling components, results in disintegration of the pial BM and overmigration of cortical neurons into the marginal zone and subarachnoid space (Graus-Porta et al., 2001; Moore et al., 2002; Beggs et al., 2003; Niewmierzycka et al., 2005; Belvindrah et al., 2007; Myshrall et al., 2012). However, it remains elusive how the integrity of the radial glial scaffold is regulated by extrinsic signals and how it contributes to the cellular organizations of the spinal cord, which has a unique and intimate interface with the PNS.

Like the rest of the CNS, the developing spinal cord is covered by the pial BM (Timpl and Brown, 1996; Halfter et al., 2002), the stability of which is supported by the overlying pial meninges and the underlying glia limitans, which is composed of interconnected radial glial endfeet during early development (Rakic, 1972, 2003; Sievers et al., 1994; Halfter et al., 2002; Zarbalis et al., 2007). At the same time, the spinal cord pial BM must be breached at the ventral motor axon exit point (MEP) and the dorsal root entry zone (DREZ) for the passage of motor and sensory axons (Fraher, 1997; Golding and Cohen, 1997). Boundary cap (BC) cells, which are derived from the neural crest and of PNS origin, are positioned over these breaches in the pial BM from outside of the 
developing spinal cord (Altman and Bayer, 1984; Niederländer and Lumsden, 1996; Golding and Cohen, 1997). Therefore, the cellular components of the CNS and PNS are interfaced directly at the DREZ and MEP.

The chemokine CXCL12 is expressed ubiquitously in developing pial meninges and, together with its receptors CXCR4 and CXCR7, regulates a large range of processes during the development of the nervous system (Zhu and Murakami, 2012). Previously, we observed CXCR4 expression in the VZ (suggestive of radial glia expression) of the developing spinal cord (Y.Z., unpublished observation). The locations of CXCL12 and CXCR4 expression, together with an established proadhesive role of CXCL12 signaling (Kinashi, 2005), prompted us to postulate that CXCL12 signaling might be an extrinsic factor that regulates the radial glial scaffold integrity during spinal cord development. Here, we investigated this hypothesis and probed the underlying mechanisms by using null mutants, cell-type-specific conditional mutants, and in vitro cell adhesion assays.

\section{Materials and Methods}

Animals. The generation of Cxcl12 knock-out (Nagasawa et al., 1996), Cxcr4 knock-out (Tachibana et al., 1998), Cxcr7 knock-out (Sierro et al., 2007), floxed (fl) Cxcr4 (Tokoyoda et al., 2004), Wnt1-Cre (Danielian et al., 1998), Nestin-CreER ${ }^{\mathrm{T} 2}$ (shortened as Nes-CreER ${ }^{\mathrm{T} 2}$; Imayoshi et al., 2006), and Z/EG responder mice with Cre-mediated recombination (Novak et al., 2000) have all been described previously. A BAC transgenic line carrying EGFP under the control of a Cxcr4 promoter/enhancer element, $\operatorname{Tg}(\mathrm{Cxcr} 4$-EGFP), was developed by the GENSAT project (Gong et al., 2003) and purchased from Mutant Mouse Regional Resource Center [strain name: $\operatorname{Tg}(\mathrm{Cxcr} 4-\mathrm{EGFP}) 73 \mathrm{Gsat}$ ]. Compound transgenic lines used for conditional knock-out experiments were generated by crossing either the Wnt1-Cre or Nestin-CreER ${ }^{\mathrm{T} 2}$ with $\mathrm{Cxcr} 4(\mathrm{fl} / \mathrm{fl})$ to generate mice with genotype Wnt1-Cre:Cxcr4(fl/+) or Nestin-CreER ${ }^{\mathrm{T} 2}: \operatorname{Cxcr} 4(\mathrm{fl} /+)$, which were subsequently crossed with $\mathrm{Cxcr} 4(\mathrm{fl} / \mathrm{fl})$ to generate embryos of desired genotypes. For expression studies, timed pregnant wild-type ICR mice (Nihon) were used. For dissociated culture of spinal radial glia, GFP-positive embryos from crossing $\mathrm{Tg}$ (Cxcr4-EGFP) and ICR mice were used. For embryo staging, 12:00 P.M. of the day on which the vaginal plug was detected was designated as embryonic day 0.5 (E0.5). Embryos of either sex were analyzed in this study. All animal maintenance and manipulations were performed in accordance with the Guidelines for Animal Experiments at Osaka University.

DNA constructs. DNA constructs for generating in situ hybridization probes are as follows. Cxcr4, Krox20 (a kind gift from Dr. David Wilkinson, National Institute for Medical Research, London, UK) and Sox10 (a kind gift from Dr. Michael Wegner, University of Erlangen-Nürnberg, Germany) constructs have all been described previously (Wilkinson et al., 1989; Kuhlbrodt et al., 1998; Zhu et al., 2009). DNA constructs carrying a region encompassing nt 352-1442 of Cxcr7 mRNA (accession BC015254) and nt 2030-3300 of mouse integrin $\beta 1$ mRNA (accession number: NM_010578) were used to generate Cxcr7 and Integrin $\beta 1$ in situ probes, respectively.

In situ hybridization and immunohistochemistry. The trunks of mouse embryos containing the spinal cord at the lumbosacral, thoracic, or cervical level were dissected out in cold PBS, pH 7.4, and fixed in 4\% paraformaldehyde (PFA, $0.1 \mathrm{M}$ PBS) at $4^{\circ} \mathrm{C}$ for $4-6 \mathrm{~h}$. These tissues were then cryoprotected in $30 \%$ sucrose (in PBS) overnight at $4^{\circ} \mathrm{C}$ and embedded in OCT (Sakura FineTek). Frozen sections were cut with a cryostat at 20 $\mu \mathrm{m}$. Sections for CXCR4/Ki67 double immunohistochemistry were cut at $16 \mu \mathrm{m}$.

In situ hybridization (ISH) on frozen sections was performed as described previously (Hasegawa et al., 2004). Hybridization of all probes was performed at $65^{\circ} \mathrm{C}$ overnight with the exception of Krox 20 , which was performed at $70^{\circ} \mathrm{C}$. For Cxcr4 and Cxcr7 double fluorescence ISH, Cxcr4 probe was labeled with digoxigenin (DIG) and Cxcr7 probe with fluorescein. Procedures up to posthybridization washing were the same as for color ISH, as described in Hasegawa et al. (2004). Thereafter, sections were subjected to sequential steps of visualizing fluorescein and DIG signals. Sections were first incubated with anti-fluorescein-POD Fab fragment (Roche) and signals were amplified with a TSA plus fluorescein system (PerkinElmer). Then, peroxidase activity was quenched in $3 \% \mathrm{H}_{2} \mathrm{O}_{2}$ for $1 \mathrm{~h}$, sections were subsequently incubated with anti-DIGPOD Fab fragment, and signals were amplified with a TSA Plus Cynine3 system (PerkinElmer). All steps essentially followed the instructions of the TSA Plus system.

Immunohistochemistry on frozen sections was performed essentially as follows. Frozen sections were brought to room temperature (RT) and washed in PBS before blocking in PBST (PBS with $0.2 \%$ Triton X-100) with $10 \%$ of the appropriate animal serum for $1 \mathrm{~h}$ at RT. Primary antibody binding was performed in PBST overnight at $4^{\circ} \mathrm{C}$. After washing, slides were incubated with secondary antibodies in PBST for $2 \mathrm{~h}$ at RT. The slides were then washed and nuclear stained with $0.03 \%$ 4,6diamidino 2-phenylindole (DAPI; Nacalai Tesque) for $15 \mathrm{~min}$ and mounted in Mowiol (Calbiochem) with 2.5\% 1,4-diazabicyclo$[2,2,2]$ octane (DABCO; Sigma-Aldrich). The primary antibodies used were goat polyclonal anti-CXCR4 (1:300, ab1670; Abcam), rabbit antiGFP (1:800, A-11122; Invitrogen), mouse monoclonal antibody to neuronal class III $\beta$-tubulin (1:500, clone TUJ1; Covance), rabbit antilaminin (1:1000, L9393; Sigma-Aldrich), rabbit anti-Nestin (1:500, a kind gift from Dr. Yasuyoshi Arimatsu, Mitsubishi Kagaku Institute of Life Sciences, Japan), RC2 monoclonal antibody (1:50; Developmental Studies Hybridoma Bank, University of Iowa), rabbit anti-phosphohistone H3 (1:200, \#06-570; Millipore), and rabbit anti-Ki67 (1:400; NCL-Ki67p; Novocastra Laboratories). The secondary antibodies used were Cy3-donkey anti-goat IgG (1:300; Jackson ImmunoResearch) for CXCR4; Alexa Fluor 488-donkey anti-rabbit IgG (1:500; Invitrogen) for GFP, laminin and Nestin and phosphor-histone H3, Ki67; FITC-donkey anti-mouse IgG (1:200; Jackson ImmunoResearch) for TUJ1; and Cy3goat anti-mouse IgM (1:200; Jackson ImmunoResearch) for RC2.

For CXCR4/Ki67, BrdU, and integrin $\beta 1 /$ laminin immunohistochemistry, modified procedures were used. For CXCR4/Ki67 double immunohistochemistry, CXCR4 single immunohistochemistry was first performed as above. The slides were then postfixed in 4\% PFA for $10 \mathrm{~min}$ and subjected to antigen retrieval by incubating in $0.01 \mathrm{M}$ citric acid buffer, $\mathrm{pH} 6.0$, at $99^{\circ} \mathrm{C}$ for $20 \mathrm{~min}$ and then the slides were immunostained with a Ki67 antibody following the general immunohistochemistry protocol above. For BrdU staining, sections were first incubated in citrate antigen retrieval buffer $(0.01 \mathrm{M}$ citric acid, $\mathrm{pH} 6.0)$ at $99^{\circ} \mathrm{C}$ for 20 min, followed by $1 \mathrm{~N} \mathrm{HCl}$ treatment for $30 \mathrm{~min}$ and washing 3 times in PBST. The rest of the procedure followed the general immunohistochemistry protocol above. Rat BrdU monoclonal antibody (ab6326; Abcam) was used at 1:200, followed by incubation with Cy3-goat anti-rat IgG (1:200; Jackson ImmunoResearch). For integrin $\beta 1 /$ laminin double immunohistochemistry on tissue sections, sections were first subjected to antigen retrieval by incubating the slides in HistoVT one (Nacalai Tesque) at $70^{\circ} \mathrm{C}$ for $20 \mathrm{~min}$. Integrin $\beta 1$ immunohistochemistry was performed using a TSA PLUS DNP system (PerkinElmer). The primary anti-activated integrin $\beta 1$ antibody, clone 9EG7 (1:10, 550531; BD Biosciences) was incubated with sections at $4^{\circ} \mathrm{C}$ overnight, followed by incubation with HRP-conjugated goat anti-rat IgG (1:2000; Jackson ImmunoResearch) for $90 \mathrm{~min}$ at RT. After TSA Plus DNP amplification, deposited DNP was visualized by incubation with Alexa Fluor 488conjugated anti-DNP-KHL (1:500; Invitrogen) for $2 \mathrm{~h}$ at RT. The sections were then immunostained with a laminin antibody as described above with Cy3-goat anti-rabbit IgG (1:300; Jackson ImmunoResearch) as a secondary antibody.

Images of ISH and immunohistochemistry on frozen sections were captured using an upright fluorescence microscope (BX-60; Olympus) coupled with a CCD camera (Axiocam; Zeiss), with $4 \times$ [UPlanApo, numerical aperture (NA) 0.16], $10 \times$ (UPlanApo, NA 0.40), and $20 \times$ (UPlanApo, NA 0.70) objective lenses. Images of CXCR4/Ki67 double immunohistochemistry were captured using a laser scanning confocal microscope (TCS SP2 AOBS; Leica Microsystems) with a $20 \times$ (N Plan, NA 0.40) objective lens. High-magnification images of CXCR4/Nestin and 9EG7/laminin double immunohistochemistry were captured using a 
laser scanning confocal microscope (TCS SP5; Leica Microsystems) with a $40 \times$ (N Plan, NA 0.65) objective lens.

Procedure of tamoxifen induction of Cre-ER ${ }^{T 2}$. Tamoxifen (SigmaAldrich), dissolved in corn oil at $20 \mathrm{mg} / \mathrm{ml}$, was administered by oral gavage to pregnant mothers made from crossing Nes-CreERT2/ Cxcr4(fl/ + ) and Cxcr4(fl/fl) lines at $1 \mathrm{mg} / 10 \mathrm{~g}$ of body weight at E9.5 and again at E10.5.

BrdU pulse labeling. BrdU (Sigma-Aldrich) was administered intraperitoneally to pregnant mothers at $0.5 \mathrm{mg} / 10 \mathrm{~g}$ of body weight. The pregnant mice were killed after $2 \mathrm{~h}$ and their embryos were then dissected, fixed, embedded, and sectioned, followed by BrdU immunohistochemistry (see above).

Dissociation of embryonic spinal cord cells. E12.5 embryos of genotype $\mathrm{Tg}(\mathrm{Cxcr} 4-\mathrm{EGFP}) /+$ were dissected quickly in calcium- and magnesiumfree Hank's buffered salt solutions (CMF-Hanks) to obtain spinal cords. Segments of the spinal cords were then opened along the roof plate. The pial meninges and dorsal and ventral roots were then carefully scraped away with a fire-polished tungsten needle. The cleaned-up spinal cord tissue fragments from 4-6 embryos were then collected into a $14 \mathrm{ml}$ Falcon tube and washed once in CMF-Hanks. The tissues were then suspended in $2 \mathrm{ml}$ of a sterilized and preactivated enzymatic mixture of papain (6 units/ml; Nacalai Tesque) and DNase 1 (30 $\mu \mathrm{g} / \mathrm{ml}$; SigmaAldrich) and rocked gently at RT for $17 \mathrm{~min}$. The enzymes were then removed and tissue fragments were washed three times in DMEM-F12 (Sigma-Aldrich), followed by trituration with a glass Pasteur pipette for $30-40$ times and then a flame-bored Pasteur pipette for a further 30-40 times. The dissociated solution was then passed through a prewet $70 \mu \mathrm{m}$ cell strainer and the cell number was counted for further experiments.

Cell adhesion assay. A 48 well tissue culture plate (Iwaki) was coated with BM components as follows. For fibronectin, stock fibronectin (1 $\mathrm{mg} / \mathrm{ml}$; Sigma-Aldrich) was quickly thawed and diluted in PBS to a final concentration of $40 \mu \mathrm{g} / \mathrm{ml}$. For laminin/poly-L-lysine coating, stock laminin $\left(2 \mathrm{mg} / \mathrm{ml}\right.$; BD Biosciences) was slowly thawed at $4^{\circ} \mathrm{C}$ and diluted in $\mathrm{H}_{2} \mathrm{O}$ (final concentration: $20 \mu \mathrm{g} / \mathrm{ml}$ ) with poly-L-lysine (final concentration: $50 \mu \mathrm{g} / \mathrm{ml}$; Sigma-Aldrich). Next, $300 \mu$ l of either fibronectin or laminin mixture was laid onto each well and coating was performed at $4^{\circ} \mathrm{C}$ overnight. All wells were then washed with PBS 3 times and blocked in $400 \mu \mathrm{l}$ of $0.5 \%$ BSA (dissolved in PBS) for $1 \mathrm{~h}$ at RT. After blocking, the wells were washed once with PBS and kept in warm DMEM-F12 until use.

The density of dissociated spinal cord cells prepared as described above was adjusted to $5 \times 10^{5} \mathrm{cells} / \mathrm{ml}$ in DMEM-F12 and the cell suspension was divided into 2 tubes, with 1 serving as a control and the other receiving recombinant CXCL12 protein (final concentration: $100 \mathrm{ng} / \mathrm{ml}$; PeproTech). The cells were recovered in a $\mathrm{CO}_{2}$ incubator for $10 \mathrm{~min}$. DMEM-F12 in each coated well was then replaced with $300 \mu$ l of control or CXCL12-added spinal cord cells. These cells were allowed to adhere at $37^{\circ} \mathrm{C}$ in a $\mathrm{CO}_{2}$ incubator for $2 \mathrm{~h}$. The plate was then shaken using a microplate shaker at $1300 \mathrm{rpm}$ for $15 \mathrm{~s}$ and washed once in DMEM-F12 to remove loosely attached cells. Cells that remained attached were then fixed in 4\% PFA at RT for $20 \mathrm{~min}$ and washed in PBS. GFP-positive adhered cells were imaged with a laser scanning confocal microscopy (FV1000; Olympus). On average, 7-9 separate view fields of each well were imaged with a $10 \times(\mathrm{CPlanFl}, \mathrm{NA} 0.30)$ objective lens under $488 \mathrm{~nm}$ laser excitation for GFP signals.

Integrin $\beta 1$ antibody binding on living cells and immunocytochemistry. Twelve-millimeter round coverslips (Matsunami) were cleaned by soaking in $1 \mathrm{~N} \mathrm{HCl}$ solution at $55^{\circ} \mathrm{C}$ for $4 \mathrm{~h}$, followed by extensive washing and then sonication and sterilization in $70 \%$ ethanol. The coverslips were then placed into the wells of a 24 well plate (Nunc) and their surfaces were coated with $450 \mu \mathrm{l}$ of laminin $(20 \mu \mathrm{g} / \mathrm{ml}$; BD Biosciences $)$ and poly-Llysine $\left(200 \mu \mathrm{g} / \mathrm{ml}\right.$; Sigma-Aldrich) in $\mathrm{H}_{2} \mathrm{O}$ at $37^{\circ} \mathrm{C}$ overnight. The coverslips were then washed in $\mathrm{H}_{2} \mathrm{O}$ three times and kept in DMEM-F12 until use. Dissociated spinal cord cells from E12.5 Tg(Cxcr4-EGFP)/+ embryos prepared as described above were plated on these coverslips at $4 \times$ $10^{4}$ cells per well in $500 \mu \mathrm{l}$ of culture medium comprising DMEM-F12 (Sigma-Aldrich), 1xN2 supplement (Life Technologies), 1xB27 supplement (Life Technologies), and recombinant human bFGF (final concentration, $20 \mathrm{ng} / \mathrm{ml}$; PeproTech). Cells were allowed to adhere to coated coverslips and cultured in the same medium for $3 \mathrm{~d}$ in a $37^{\circ} \mathrm{C} \mathrm{CO}_{2}$ incubator. The culture medium was then removed and replaced with $37^{\circ} \mathrm{C}$ DMEM-F12 and the cells were kept in DMEM-F12 at $37^{\circ} \mathrm{C} \mathrm{CO}_{2}$ incubator for $3 \mathrm{~h}$. Half of the wells were then stimulated with recombinant CXCL12 protein (final concentration: $200 \mathrm{ng} / \mathrm{ml}$; PeproTech) in DMEM-F 12 at $37^{\circ} \mathrm{C}$ for $30 \mathrm{~min}$ and the other half were kept in DMEMF12 under the same conditions to serve as a control. The cells were then incubated with a low concentration of rat anti-mouse integrin $\beta 1$ chain antibody (9EG7, 550531; BD Biosciences) at $0.5 \mu \mathrm{g} / \mathrm{ml}$ for $30 \mathrm{~min}$ in a $37^{\circ} \mathrm{C} \mathrm{CO}_{2}$ incubator. Cells were quickly washed twice with DMEM-F12 and fixed in 4\% PFA for 20 min at RT, followed by several washes with PBS. After blocking in PBS with 10\% goat serum, cells were incubated with a secondary antibody of Cy3-anti-rat IgG (1:300; Jackson ImmunoResearch) in PBS for $2 \mathrm{~h}$ at RT followed by several PBS washes. The coverslips were then mounted in Mowiol/DABCO for imaging. Cells were imaged with a $20 \times($ UPlanApo, NA0.70) objective lens using an upright fluorescence microscope (BX-60; Olympus) coupled with a CCD camera (Axiocam; Zeiss) for GFP and Cy3-detected 9EG7 signals.

Quantification and statistics. For cell adhesion assays, GFP-positive cells on each imaged view field were counted either manually or with the aid of an image processing program (ImageJ). Normalized data were pooled from five or two independent experiments for fibronectin and laminin/poly-L-lysine (PLL), respectively. The number of cells adhered were compared statistically between control and CXCL12-treated sample groups using the Mann-Whitney $U$ test.

For quantitative immunocytochemistry after 9EG7 binding on dissociated radial glia cells, the image-processing program MetaMorph version 2.0 (Universal Imaging) was used. Dissociated cells from E12.5 spinal cords and cultured on laminin-coated coverslips in bFGFcontaining medium include many Nestin-positive and $\beta 3$-tubulinnegative cells that display bipolar radial morphology (Y.Z., unpublished observation). We therefore chose GFP-positive cells that showed radial morphology for quantitative analysis. The outline of each cell was drawn from its GFP signal profile and the average Cy3 signal over the total cell area was measured with MetaMorph. Cy3 signals measured from 509 control cells and 634 CXCL12-treated cells pooled from four independent experiments were compared statistically using Student's $t$ test.

\section{Results \\ Expression of CXCR4 in radial glia and BC cells during spinal cord development}

To address the potential function of CXCR4 and CXCL12 in radial glial development in the spinal cord, we first examined CXCR4 expression patterns during the active period of neurogenesis between E9.5 and E14.5. ISH showed that Cxcr4 mRNA was mainly expressed in the motor column at E9.5 and downregulated at E10.5 (data not shown; Fig. 1A), consistent with a previous report (Lieberam et al., 2005). From E10.5, Cxcr4 mRNA within the neural tube was predominantly confined to the $\mathrm{VZ}$ and detectable across the entire dorsoventral span of the VZ, although the signal was comparatively weaker and patchier within the dorsal half (Fig. $1 A-C$, arrowheads). The CXCR4 protein was expressed in a similar pattern to its mRNA (Fig. $1 D$, arrowhead). The spinal cord VZ comprises neural progenitor cells that are, like their counterparts in the brain, radial glia cells with basal processes that extend and attach to the pial BM via their pial endfeet (Misson et al., 1988; Rakic, 2003; Anthony et al., 2004). We therefore investigated whether CXCR4 was expressed in radial glia cells. To address this question, we used a mouse transgenic line in which the expression of EGFP is under the control of Cxcr4 promoter/enhancer elements (Gong et al., 2003) that has been shown to recapitulate CXCR4 expression pattern in the nervous system (Tran et al., 2007). On a transverse section of the E12.5 spinal cord, an EGFP signal was detected in the VZ as well as the radial processes that emanated from the VZ (Fig. $1 F, G)$. The EGFP signal in these radial processes was colocalized 


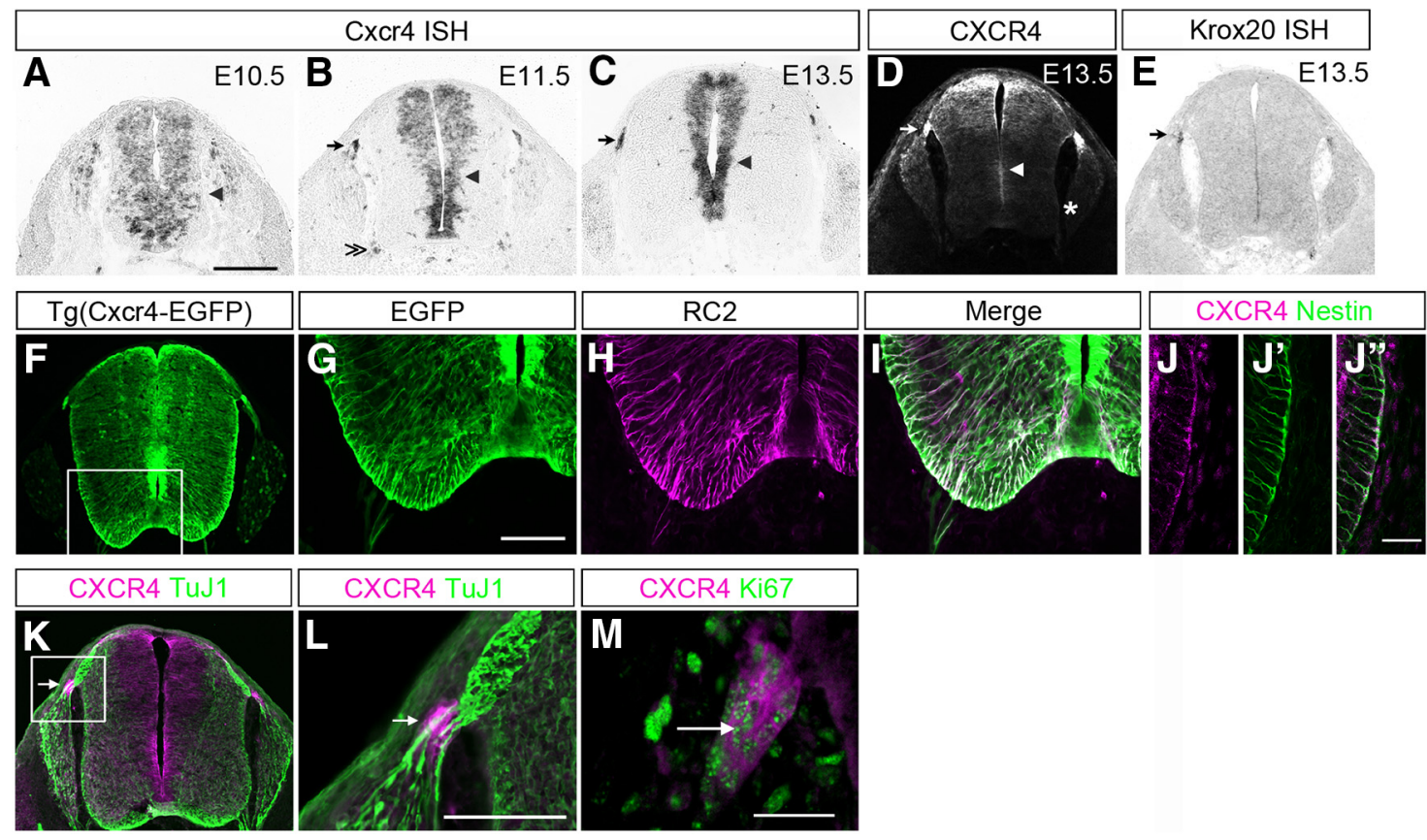

Figure 1. Expression of CXCR4 in and around developing mouse spinal cords. $\boldsymbol{A}-\boldsymbol{D},(\mathrm{Cx}$ Cr4 ISH on transverse sections of spinal cords at E10.5 (A), E11.5 (B), and E13.5 ( $(\boldsymbol{C})$ and immunohistochemistry on an E13.5 transverse spinal cord section (D) showing (xcr4 mRNA and protein distribution across the VZ (arrowheads) as well as clusters of cells at the DREZ (arrows) and MEP ( $\boldsymbol{B}$, double arrowhead). $\boldsymbol{E}$, Krox20 ISH on an E13.5 transverse spinal cord section adjacent to the section shown in $\boldsymbol{D}$. The arrow indicates the Krox20-positive BC cell cluster. $\boldsymbol{F}, A$ transverse section from an E13.5 $\mathrm{Tg}(\mathrm{Cxcr4-EGFP)}$ spinal cord shows GFP signals in the VZ and radial processes emanating from it. $\mathbf{G}-\boldsymbol{I}$, High-magnification views of the boxed area in $\boldsymbol{F}$ highlighting the GFP-positive radial processes (G) colocalized with RC2 antigenicity ( $\boldsymbol{H}$, merged image in $\boldsymbol{I}) . \boldsymbol{J}, \boldsymbol{J}^{\prime}, \boldsymbol{J}^{\prime \prime}$, High-magnification views of an E13.5 spinal cord transverse section with double immunohistochemistry of $\mathrm{CXCR4}$ and Nestin show that CXCR4 protein is present in the endfeet of the spinal cord radial processes. The region shown is approximately corresponding to the asterisked region in $\boldsymbol{D} . \boldsymbol{K}, \boldsymbol{L}, \mathrm{CXCR} 4$ and TuJ1 double immunohistochemistry on an E13.5 spinal cord section show CXCR4-positive clusters capping the incoming sensory axons at the DREZ, indicating their nature as BC cells. A high-magnification view of boxed area in $\boldsymbol{K}$ is shown in $\boldsymbol{L} . \boldsymbol{M}$, CXCR4 and Ki67 double immunohistochemistry show that most CXCR4-positive cells at DREZ are proliferating (arrow). Scale bars: $\boldsymbol{A}-\boldsymbol{F}, \boldsymbol{K}, 200 \mu \mathrm{m} ; \boldsymbol{G}-\boldsymbol{I}, 100 \mu \mathrm{m}$; $J, J^{\prime}, J^{\prime \prime}, 25 \mu \mathrm{m} ; L, 100 \mu \mathrm{m} ; M, 25 \mu \mathrm{m}$.

with RC2 antigenicity, a marker for radial glia (Fig. 1G-I) (Misson et al., 1988). Finally, double immunohistochemistry for CXCR4 and Nestin, the latter a marker for radial glia (Hockfield and McKay, 1985; Lendahl et al., 1990; Anthony et al., 2004), revealed a CXCR4-positive signal along the surface of the spinal cord that is colocalized with the Nestin-positive radial glial endfeet (Fig. $\left.1 J, J^{\prime}, J^{\prime \prime}\right)$. These data suggest that CXCR4 was indeed expressed in the spinal cord radial glial cells.

We noticed that CXCR4 was also expressed in small clusters of cells immediately adjacent to the neural tube. These cells were located at positions suggestive of the DREZ and MEP (Fig. $1 B-D$, arrows, $B$, double arrowhead). Because BC cells are known to position at the DREZ and MEP and to associate tightly with dorsal and ventral roots, we investigated whether CXCR4 was expressed in BC cells. Krox20 (also known as Egr2) is a well established BC cell marker in mice (Wilkinson et al., 1989; Schneider-Maunoury et al., 1993; Topilko et al., 1994). We found that the CXCR4- and Krox20-expressing cell clusters on adjacent sections were similar in their positioning and appearances (Fig. $1 D, E$, arrows). Using CXCR4 and TuJ1 double immunohistochemistry, we found that CXCR4-expressing cell clusters associated tightly with the sensory and motor axon roots at the DREZ and MEP, respectively (Fig. $1 K, L$, arrows, and data not shown). Finally, CXCR4 and Ki67 double immunohistochemistry showed that $\sim 90 \%$ of the CXCR4-positive BC cells were proliferating (Fig. $1 M$, arrow). These latter two pieces of evidence are consistent with the original definition of BC cells (Altman and Bayer, 1984; Golding and Cohen, 1997). It should be noted that CXCR4 expression in the dorsal BC persisted until at least E14.5, the latest developmental stage examined in this study, and that CXCR4 expression in the ventral BC appeared weaker in comparison and became undetectable at E14.5 (Fig. 1B, C, and data not shown). Together, these data suggest that CXCR4 is expressed in BC cells of the developing spinal cord.

\section{Defective radial glia development and $\mathrm{BC}$ cell positioning in Cxcl12/Cxcr4-deficient mice}

The expression of CXCR4 in radial glia and BC cells raised the possibility that CXCR4 plays important roles in the development and function of these cells. To test this possibility, we examined spinal cords from Cxcl12 knock-out embryos.

First, we examined radial glia and their scaffold by Nestin immunohistochemistry on E13.5 spinal cords. Nestin, a commonly used marker for neural stem cells, is an intermediate filament enriched in radial glia, their processes, and endfeet (Hockfield and McKay, 1985; Lendahl et al., 1990; Anthony et al., 2004). In wild-type spinal cord, we observed that Nestin-positive radial glial processes extended radially toward the pial surface and Nestin-positive pial endfeet formed a continuous coverage over the surface of the spinal cord (Fig. $2 A, C, G, n=3 / 3$ ). In contrast, in $\mathrm{Cxcl} 12^{-/-}$spinal cord, gaps in the pial endfeet layer were detected at various positions between the DREZ and MEP (Fig. $2 B, D, H$, arrows, $n=4 / 4$ ). Adjacent to these gaps, the termini of radial processes appeared stunted and some deviated from the radial orientation (Fig. $2 D, H$ ). Such deviated radial processes could also be seen deep within the mantle layer (Fig. $2 \mathrm{D}, \mathrm{H}$, arrowheads). This defect in the radial glial scaffold was also observed in Cxcr4 knock-out mice (data not shown). Therefore, CXCL12/CXCR4 signaling appears to be critical for maintaining the integrity of the radial glial scaffold. 

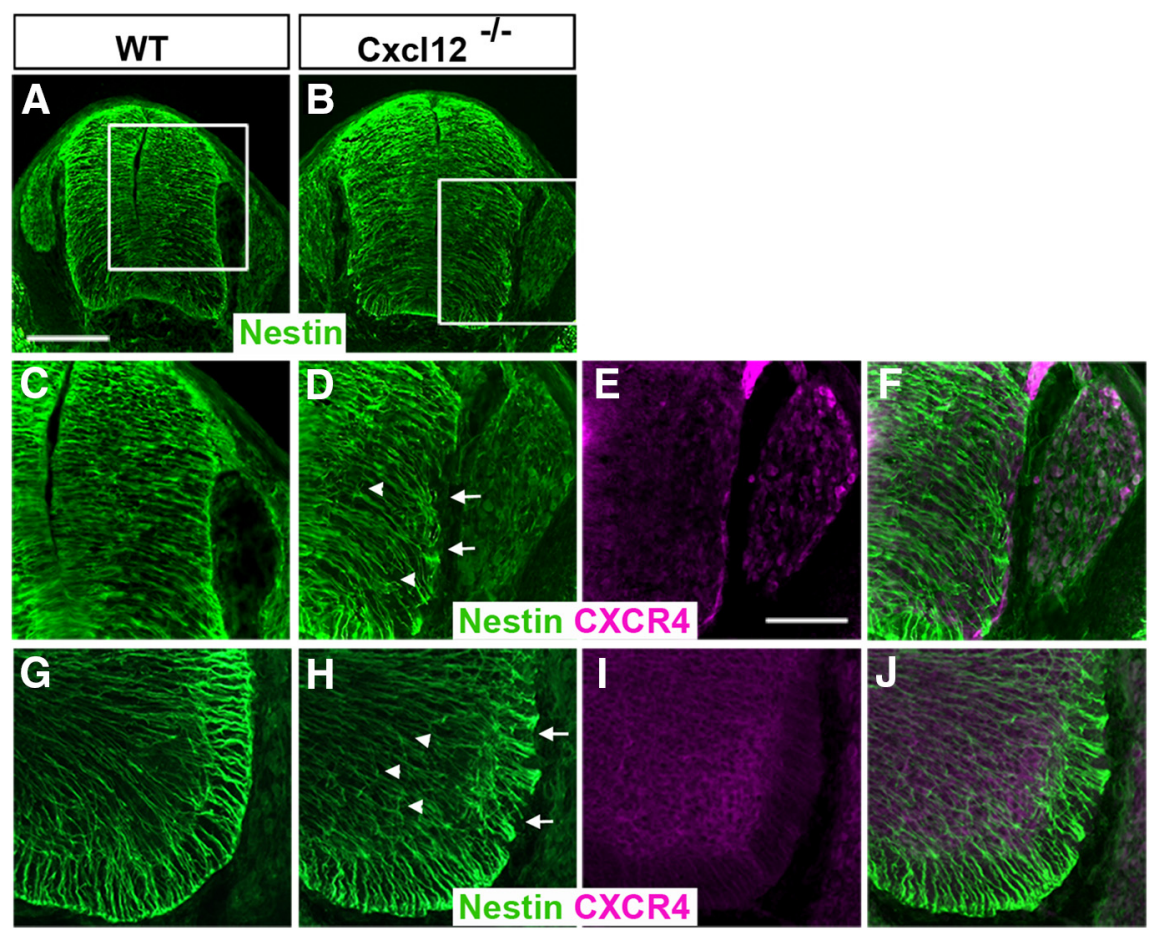

Figure 2. The radial glial scaffold is disrupted in $\operatorname{Cxc1} 12 / C x c r 4$ deficient spinal cord. $\boldsymbol{A}, \boldsymbol{B}$, Nestin immunohistochemistry on $\mathrm{E} 13.5$ wild-type $(\boldsymbol{A})$ and $(x \mathrm{Cl} 12$ knock-out $(\boldsymbol{B})$ spinal cords at lumbosacral levels. $\boldsymbol{C}, \boldsymbol{D}$, High-magnification views of the boxed areas in $\boldsymbol{A}$ and $\boldsymbol{B}$, respectively. The radial glial scaffold appears defective in (xcl12-knock-out mice with a disrupted pial endfeet layer (arrows) and derailed and stunted radial processes $(\boldsymbol{B}, \boldsymbol{D}$, arrowheads). $\boldsymbol{E}, \boldsymbol{F}$, Same section as in $\boldsymbol{D}$ double immunostained with CXCR4 ( $\boldsymbol{E}$, merged image in $\boldsymbol{F}$ ) show that ectopic (XCR4-positive cells are often located at gaps of the pial endfeet layer at the lumbosacral level. $\boldsymbol{G}, \boldsymbol{H}$, High-magnification views of E13.5 wild-type $(\boldsymbol{G})$ and $(x \mathrm{Cl} 12 \mathrm{knock}$-out $(\boldsymbol{H})$ spinal cord sections at the thoracic level with Nestin immunohistochemistry show that the disrupted radial glial scaffold (arrows and arrowheads) persists at the thoracic level. $\boldsymbol{I}, \boldsymbol{J}$, Same section as in $\boldsymbol{H}$ double immunostained with CXCR4 (I, merged image in $\boldsymbol{J}$ ) show that gaps in the pial endfeet layer are not necessarily correlated with the presence of ectopic CXCR4-positive cells, which are themselves rare at the thoracic level. Scale bars: $A, B, 200 \mu \mathrm{m} ; \boldsymbol{C}-\boldsymbol{J}, 100 \mu \mathrm{m}$.

Next, we examined BC cells and their positions by CXCR4 and laminin double immunohistochemistry. In E13.5 $\mathrm{Cxcl}_{12}^{-1-}$ spinal cord, BC cells at the DREZ appeared highly abnormal. Rather than capping the DREZ from outside, BC clusters were often seen to locate further into the spinal cord (cf. Fig. $3 B, D$ vs $A, C, n=$ 4/4). Strikingly, cell clusters that expressed high levels of CXCR4 were found between the DREZ and MEP within the boundary of the spinal cord delineated by laminin staining (Fig. $3 B, D, F$, arrowheads, $n=4 / 4$ ). Krox20 ISH unveiled similarly located ectopic Krox20-positive cells in Cxcl12 $2^{-/-}$spinal cords (cf. Fig. $3 \mathrm{H}$ vs $G)$. Given that, at this developmental stage, Krox20 is exclusively expressed in BC cells in the spinal cord (Topilko et al., 1994), this result suggested that $\mathrm{BC}$ cells had invaded into the spinal cord in Cxcl12 knock-out mice. Because BC cells express high levels of CXCR4, the ectopic CXCR4-positive cells seen in Figure 3, B and $D$, are highly likely to represent the invaded BC cells. To confirm that PNS cells indeed invaded into the spinal cord, we performed ISH using Sox10, a marker of neural crest derivatives that contribute to the formation of PNS glia (Kuhlbrodt et al., 1998; Britsch et al., 2001). Indeed, we found Sox10-positive ectopic cell clusters within the Cxcl12-/- (cf. Fig. $3 J$ vs $I$ ). Similar results were obtained when we performed ISH with ErbB3, a marker for neural crest-derived Schwann cell precursors (data not shown; Meyer and Birchmeier, 1995). Analysis of Cxcr4 knock-out mice using the same sets of marker staining showed the same phenotype (data not shown), implicating the involvement of CXCL12/ CXCR4 signaling in $\mathrm{BC}$ cell positioning. It should be noted that this defect was the most severe at the lumbosacral level (as shown in Fig. 3) and milder at the thoracic and cervical spinal cord, with smaller and less frequent ectopic BC clusters (data not shown). Double immunohistochemistry of Nestin and CXCR4 showed that, at the lumbosacral level, gaps in the pial endfeet layer were frequently associated with the presence of ectopic CXCR4-positive cells (Fig. 2D-F). Although gaps in pial endfeet persisted at the thoracic and cervical levels, they were often not correlated with the presence of ectopic CXCR4-positive cells, which were rare at these levels (Fig. $2 \mathrm{H}-\mathrm{J}$ ).

Together, these results show that deficiency of CXCL12/CXCR4 signaling causes a disrupted radial glial scaffold with gaps in the radial endfeet layer and an invasion of $\mathrm{BC}$ cells into the spinal cord.

Conditional Cxcr4 knock-out unveils a primary defect in radial glia leading to a secondary defect in $\mathrm{BC}$ cell positioning Above, we described defects in the radial glial scaffold and BC cell positioning in Cxcl12/Cxcr4 knock-out spinal cords. However, it remains unclear whether the two defects are causally related or independent, a question crucial to understanding the underlying mechanisms. To address this question, we created conditional Cxcr4 knock-out mice using Cre driver lines and a $\mathrm{Cxcr} 4(\mathrm{fl} / \mathrm{fl})$ transgenic line containing the floxed Cxcr4 allele.

We used a Nestin-CreER ${ }^{\mathrm{T} 2}$ (Nes$\mathrm{CreER}^{\mathrm{T} 2}$ ) driver line to specifically knock out $\mathrm{Cxcr} 4$ in radial glial cells but not in $\mathrm{BC}$ cells. We chose the Nes-CreER ${ }^{\mathrm{T} 2}$ driver line because it allows for temporally regulated recombination in CNS neural progenitors upon tamoxifen administration (Imayoshi et al., 2006). We then generated a compound transgenic line by crossing Nes-CreER ${ }^{\mathrm{T} 2}$ with the Z/EG reporter line, which expresses EGFP upon Cre-mediated recombination. Using the Nes$\mathrm{CreER}^{\mathrm{T} 2}: \mathrm{Z} / \mathrm{EG}$ line, we tested several tamoxifen administration times (data not shown) and found that tamoxifen administration at E9.5 and again at E10.5 resulted in abundant recombination across the spinal cord $\mathrm{VZ}$ and their derivatives (Fig. $4 A, B$ ), but not in BC cells (Fig. 4B-E). Next, using Nes-CreER ${ }^{\mathrm{T} 2}$ :Cxcr4(fl/ $\mathrm{fl}$ ), we examined the extent and specificity of the Cxcr4 knockout. Tamoxifen administration once at E9.5 and a second time at E10.5 led to a remarkable reduction of CXCR4 in the spinal cord VZ, but not in BC cells (Fig. $4 F-I$, arrow and arrowheads), validating the suitability of this experimental paradigm to achieve radial glia-specific conditional Cxcr4 knock-out. It should be noted that BC cells, as multipotent neural crest stem cells, have been shown to express Nestin when dissociated and cultured in stem cell medium (Belmadani et al., 2005; Hjerling-Leffler et al., 2005; Zujovic et al., 2011). However, Nestin immunohistochemistry on spinal cord sections showed that the Nestin expression level in BC cells was much lower than that in radial glia cells (data not shown), which may explain why tamoxifen administration at E9.5 and E10.5 could evade recombination in BC cells. The CXCR4 reduction in the $\mathrm{VZ}$ was much higher than what might be 

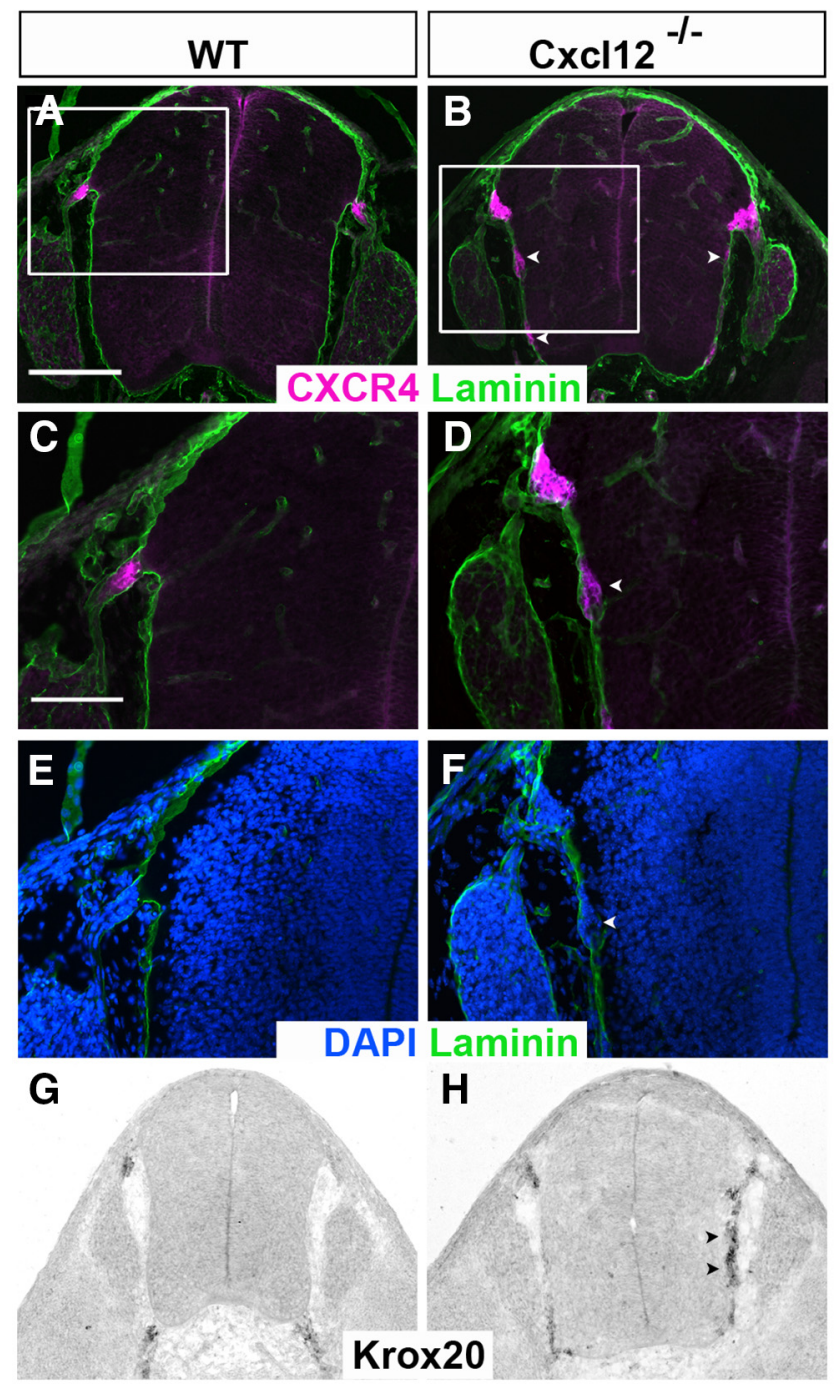

H

\begin{abstract}
H
\end{abstract}
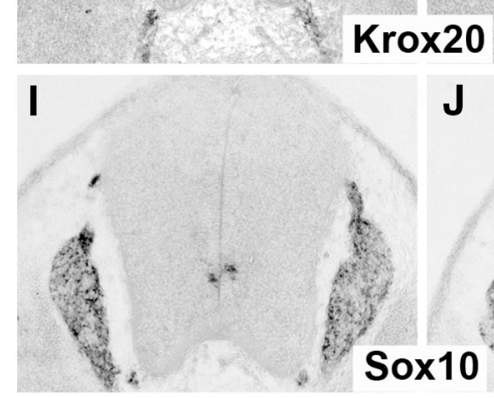

$\mathrm{J}$
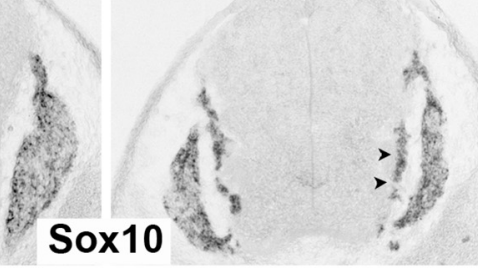

Figure 3. $B C$ cells are ectopically positioned within the Cxc12/Cxcr4 deficient spinal cord. $\boldsymbol{A}-\boldsymbol{D}, \mathrm{CXCR4}$ and laminin double immunohistochemistry on transverse sections of $\mathrm{E} 13.5$ wildtype $(\boldsymbol{A}, \boldsymbol{C})$ and $\boldsymbol{C}$ cl12 knock-out $(\boldsymbol{B}, \boldsymbol{D})$ spinal cords at the lumbosacral levels. $\boldsymbol{C}$ and $\boldsymbol{D}$ are high-magnification views of the boxed areas in $\boldsymbol{A}$ and $\boldsymbol{B}$, respectively. $\boldsymbol{E}$ and $\boldsymbol{F}$ show the same view fields as in $\boldsymbol{C}$ and $\boldsymbol{D}$, respectively, with laminin and DAPI signals. Cells expressing $C X C R 4$ at a high level similar to $B C$ cells $\left(\boldsymbol{B}, \boldsymbol{D}, \boldsymbol{F}\right.$, arrowheads) are found inside the $\mathrm{Xxcl12^{-/- }}$ spinal cord, the boundary of which is delineated by laminin immunoreactivity $(\boldsymbol{B}, \boldsymbol{D}, \boldsymbol{F}) . \mathbf{G}-\boldsymbol{J}$, ISH with

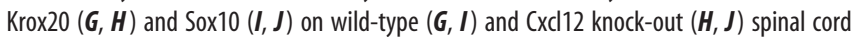
sections confirmed that the ectopic cells positioned within $C x c 112$ knock-out spinal cords are $B C$ cells of PNS origin. Scale bars: $\boldsymbol{A}, \boldsymbol{B}, \mathbf{G}-\boldsymbol{J}, 200 \mu \mathrm{m} ; \boldsymbol{C}-\boldsymbol{F}, 100 \mu \mathrm{m}$.

expected from the recombination efficiency reported by the Z/EG line, possibly because of differences in recombination efficacy between the Cxcr4-flox and Z/EG alleles. We then analyzed the radial glial scaffold of these conditional knock-out samples by Nestin immunohistochemistry. Nes-CreER ${ }^{\mathrm{T} 2}: \mathrm{Cxcr} 4(\mathrm{fl} / \mathrm{fl})$ spinal cord at E13.5 showed disruptions in pial endfeet and disarrayed radial processes, phenocopying the defects in Cxcl12 and Cxcr4- null embryos (Fig. $4 K, M$, arrows and arrowheads, $n=4 / 4$ ). Nes$\mathrm{CreER}^{\mathrm{T} 2}: \mathrm{Cxcr} 4(\mathrm{fl} /+)$ littermates with tamoxifen administration showed normal radial glial scaffold as in wild-type (Fig. $4 J, L, n=$ $2 / 2$ ), suggesting that the observed phenotype was indeed due to Cxcr4 knock-out and not tamoxifen treatment. Next, the positions of BC cells were analyzed in these samples by Cxcr4 and Sox10 ISH. Strikingly, there were many mispositioned BC cells between the DREZ and MEP in the spinal cords of E13.5 NesCreER $^{\mathrm{T} 2}:$ Cxcr4(fl/fl) (Fig. $4 O, Q$, arrowheads, $\left.n=4 / 4\right)$, but not their $\mathrm{Cxcr} 4(\mathrm{fl} /+$ ) littermates (Fig. $4 N, P, n=2 / 2$ ), phenocopying the BC cell defects observed in Cxcl12- and Cxcr4-null embryos. CXCR4 is transiently expressed in newborn motor neurons between E9.5 and E10.5 to control the proper guidance of motor axons out of the neural tube (Lieberam et al., 2005). To exclude any possible confounding effect of Cxcr4 knock-out in motor neurons, we administered tamoxifen only once at E10.5, which would lead to recombination after E11. Although this procedure led to less efficient Cxcr4 knock-out in spinal VZ, we were still able to detect defects in radial glia and BC cells, albeit to a lesser extent (data not shown).

We then used a Wnt1-Cre line to knock out Cxcr4 from the $\mathrm{BC}$ cells. Wnt1-Cre has been shown to induce efficient recombination in neural crest cells (from which BC cells derive) and in the dorsal progenitor domain of spinal cord (Danielian et al., 1998; Jiang et al., 2000; Charron et al., 2003; Hari et al., 2012). By crossing the Wnt1-Cre line with the Z/EG reporter line, we confirmed that Wnt1-Cre-mediated recombination took place in neural crest cells, as indicated by the EGFP-positive dorsal root ganglia (DRG) and dorsal/ventral roots, as well as a dorsal progenitor domain and its derivatives in the spinal cord (Fig. 5A, $B$, arrowhead and arrow). Notably, Cre-mediated recombination took place in BC cells (Fig. $5 C-E$ ), but not in most spinal cord radial glial cells ventral to the dorsal Wnt1-positive domain (Fig. $5 A, B)$. A triple compound transgenic line was then generated with Wnt1-Cre, Z/EG, and Cxcr4(fl/fl). In Wnt1-Cre:Z/EG: Cxcr4(fl/fl) samples, CXCR4 expression was markedly reduced in $\mathrm{BC}$ cells and the dorsal VZ domain (Fig. 5F-J), but preserved in the VZ ventral to the dorsal Wnt1-positive domain (Fig. 5G). The specificity of Wnt1-Cre-mediated conditional Cxcr4 knockout was further confirmed by Cxcr4 ISH on Cxcr4 (fl/fl) and Wnt1-Cre:Cxcr4(fl/fl) (Fig. 5O,P, arrow and arrowhead). Nestin staining on Wnt1-Cre:Cxcr4(fl/fl) samples showed a largely normal radial glial scaffold (cf. Fig. $5 M, N$ vs $K, L, n=3 / 3$ ), with the only exception at the DREZ, where gaps in the radial glial scaffold were observed (Fig. 5M, arrow). Sox10 ISH on Wnt1-Cre: Cxcr4(fl/fl) samples showed that invasion of PNS cells into the spinal cord was mostly absent except at the DREZ, where BC cells are positioned further into the spinal cord (cf. Fig. $5 R$ vs $Q$, arrow, $n=3 / 3$ ). Therefore, Wnt1-Cre-mediated conditional knock-out generated localized defects at DREZ, but did not recapitulate the large scale $\mathrm{BC}$ cell invasion and multiple gaps in pial endfeet that were observed in Cxcl12 and Cxcr4 null embryos (cf. Figs. 5, 2, 3).

The results from the two conditional knock-out experiments suggest that CXCL12/CXCR4 signaling has a cell autonomous role in radial glia in regulating the integrity of the radial glial scaffold. A primary defect in the disrupted radial glial scaffold leads to a secondary defect in the mispositioning of $\mathrm{BC}$ cells within the CNS. The DREZ-confined radial glia and $\mathrm{BC}$ position defect seen in Wnt1-Cre conditional knock-out mice could therefore be explained by the reduction of CXCR4 in radial glial cells within the dorsal Wnt1-positive domain of the spinal cord VZ, some of which send their radial processes toward the DREZ. 

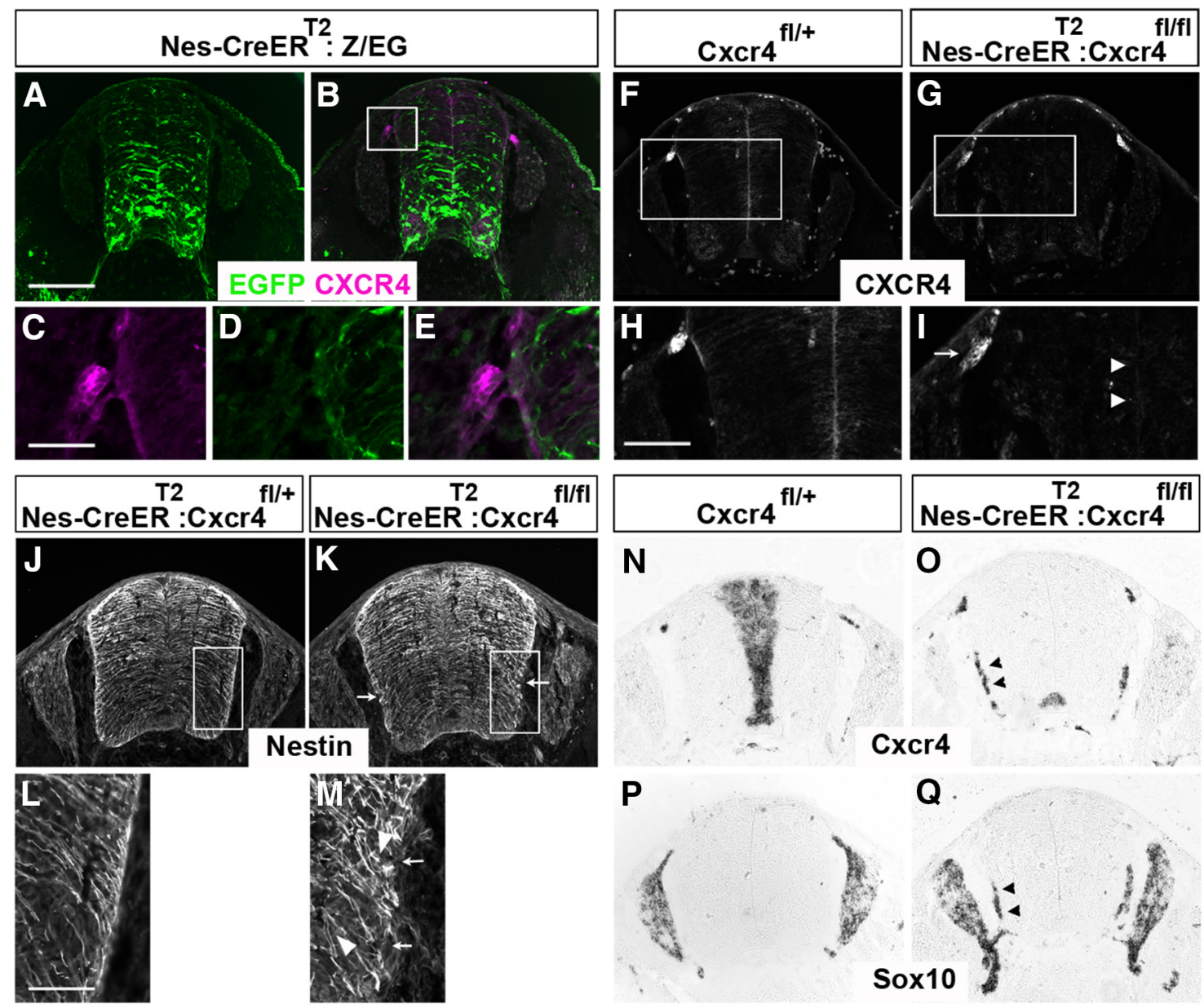

Figure 4. Conditional knock-out of CXcr4 in spinal cord radial glia. $\boldsymbol{A}-\boldsymbol{E}$, An E13.5 spinal cord section from Nes-CreER ${ }^{\mathrm{T} 2}: \mathrm{Z} / \mathrm{EG}$ compound transgenic embryo with tamoxifen administered at E9.5 and E10.5. Double immunohistochemistry with GFP and CXCR4 shows that (re-mediated recombination (GFP-positive cells) takes place in the VZ and its derivatives, but not in BC cells (B-E). $\boldsymbol{C}-\boldsymbol{E}$

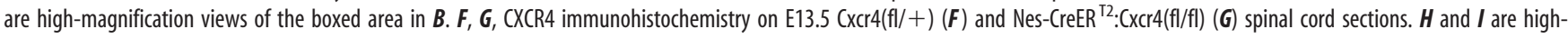
magnification views of the boxed areas in $\boldsymbol{F}$ and $\mathbf{G}$, respectively. CXCR4 expression is selectively knocked out in the VZ (G, arrowheads in $\boldsymbol{I}$ ), but not in BC cells $(\boldsymbol{G}$, arrow in $\boldsymbol{I})$. $\boldsymbol{J}-\boldsymbol{M}$, Nestin immunohistochemistry on E13.5 sections from Nes-CreER ${ }^{\mathrm{T} 2}:\left(\mathrm{Xxc} 4(\mathrm{fl} /+)(\boldsymbol{J})\right.$ and Nes-CreER ${ }^{\mathrm{T} 2}: \mathrm{Cxcr} 4(\mathrm{fl} / \mathrm{fl})(\boldsymbol{K}) \cdot \boldsymbol{L}$ and $\boldsymbol{M}$ are high-magnification views of the boxed areas in $\boldsymbol{J}$ and $\boldsymbol{K}$, respectively. The

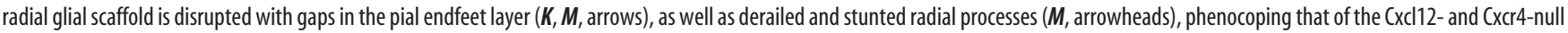

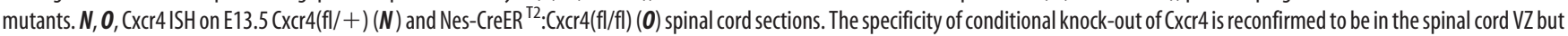

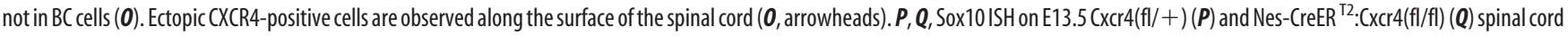
sections confirm the ectopic CXCR4-positive cells (arrowheads) are of PNS origin. The BC defects phenocopy those of the Cxcl12-and Cxcr4-null mutants. Scale bars: $\boldsymbol{A}, \boldsymbol{B}, \boldsymbol{F}, \boldsymbol{G}, \boldsymbol{J}, \boldsymbol{K}, \boldsymbol{N}, \mathbf{O}, 200 \mu \mathrm{m} ; \boldsymbol{C}-\boldsymbol{E}$, $50 \mu \mathrm{m} ; \boldsymbol{H}, \mathbf{I}, 100 \mu \mathrm{m} ; \boldsymbol{L}, M, 35 \mu \mathrm{m}$.

\section{CXCR7 expression and involvement in spinal cord development}

Although CXCR4 was once thought to be the only receptor for CXCL12, a second CXCL12 receptor, CXCR7, was later identified (Balabanian et al., 2005; Burns et al., 2006). The functions of CXCR7 appear to be context dependent, varying from serving as a scavenger receptor for shaping its ligand concentration and distribution to being an independent signaling receptor of CXCL12 to modulating CXCL12 downstream signaling via heterodimerization with CXCR4 (Zhu and Murakami, 2012). We wondered whether CXCR7 also has a role in spinal cord development. We therefore first examined its expression pattern in the developing spinal cord and then analyzed the Cxcr7 knock-out embryos (Sierro et al., 2007).

Cxcr7 ISH showed that Cxcr7 was also expressed in the VZ of the developing spinal cord. At E10.5, Cxcr7 expression was more uniform within the ventral VZ, but patchy dorsally (Fig. 6A, arrow). However, from E11.5, its expression broadened to across the entire VZ (Fig. 6B, $C$, arrows) except for a small intermediate section. Double fluorescence ISH with Cxcr7 and Cxcr4 probes on E13.5 spinal cord sections showed that the expressions of these two genes overlapped extensively, with variations observed in their relative intensities in different regions of the VZ (Fig. 6D$F$ ). Unlike Cxcr4, Cxcr7 was not detected in BC cells or the DRG outside of the spinal cord (Fig. $6 A-C$ ).

We then analyzed in Cxcr7 knock-out embryos the two aspects of spinal cord development that are affected in Cxcl12 and Cxcr4 mutants. Nestin immunohistochemistry showed that Cxcr $7^{-1-}$ spinal cord also displayed a radial glial scaffold defect with gaps in pial endfeet and disarrayed radial processes (cf. Fig. $6 H, H^{\prime}$ vs $G, G^{\prime}, n=3 / 3$ ). Sox10 ISH showed mispositioned PNS cells within the spinal cord in Cxcr7 mutant (cf. Fig. $6 J$, $J^{\prime}$ vs $I, I^{\prime}$, $n=3 / 3$ ). Both defects appeared to be milder in Cxcr7 knock-out mice than in $\mathrm{Cxcl} 12$ and $\mathrm{Cxcr} 4$ knock-out mice. The fact that CXCR7 is not expressed in BC cells provides additional support to the conclusion drawn from the conditional knock-out experiments that $\mathrm{BC}$ cell mispositioning is secondary to defects in radial glial scaffold. 

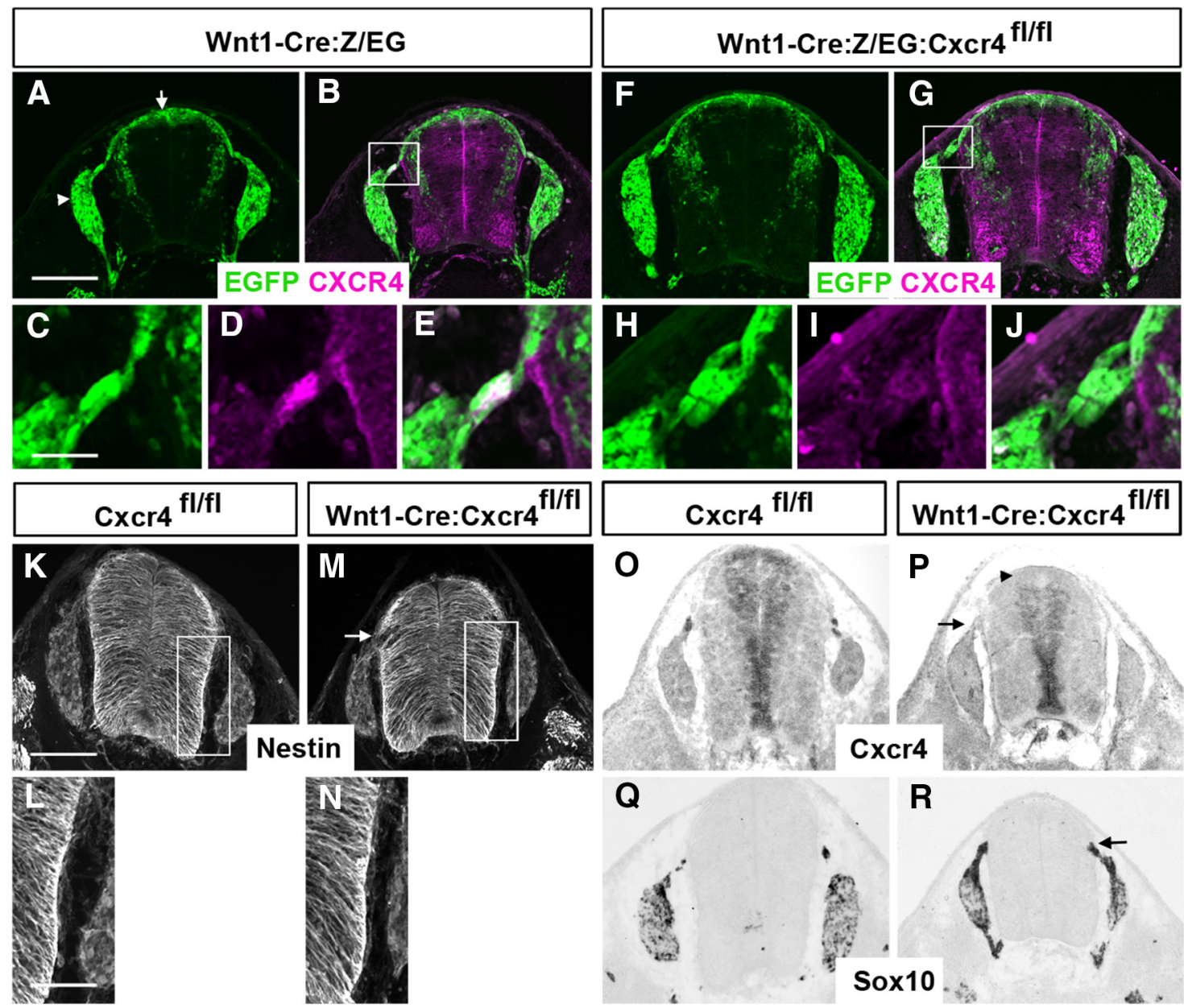

Figure 5. Conditional knock-out of CXcr4 in BC cells. $\boldsymbol{A}-\boldsymbol{E}$, An E13.5 spinal cord section from Wnt1-Cre:Z/EG compound transgenic embryo with GFP and CXCR4 immunohistochemistry. Wnt1-Cre-mediated recombination indicated by GFP-positive cells takes place in the dorsal spinal cord progenitor domain (arrow) and in neural crest cells and their derivatives (arrowhead) (A). Double immunohistochemistry of GFP and CXCR4 show that recombination takes place in BC cells $(\boldsymbol{B}-\boldsymbol{E})$, but not in the spinal cord VZ ventral to dorsal Wnt1-positive domain $(\boldsymbol{B})$. $\boldsymbol{C}-\boldsymbol{E}$ are high-magnification views of the boxed area in $\boldsymbol{B}$. $\boldsymbol{F}-\boldsymbol{J}$, An E13.5 spinal cord section from Wnt1-Cre:Z/EG:CXcr4(fl/fl) triple transgenic embryo with GFP and CXCR4 double immunohistochemistry. $\boldsymbol{H}-\boldsymbol{J}$ are high-magnification views of the boxed area in $\mathbf{G}$. Knock-out of $\mathrm{Cxcr} 4$ expression is efficient in $B C$ cells $(\boldsymbol{H}-\boldsymbol{J})$, whereas CXCR4 expression in the VZ ventral to dorsal Wnt1-positive domain is preserved $(\boldsymbol{G}) . \boldsymbol{K}-\boldsymbol{N}$, Nestin immunohistochemistry on E13.5 $\mathrm{Cxcr} 4(\mathrm{fl} / \mathrm{fl})(\boldsymbol{K}, \boldsymbol{L})$ and Wnt1-Cre:Cxcr4(fl/fl) $(\boldsymbol{M}, \boldsymbol{N})$ spinal cord sections. $\boldsymbol{L}$ and $\boldsymbol{N}$ are high-magnification views of the boxed areas in $\boldsymbol{K}$ and $\boldsymbol{M}$, respectively. The radial glial scaffold is mostly normal in Wnt1-Cre:Cxcr4(fl/fl) spinal cord $(\boldsymbol{M}, \boldsymbol{N})$, with the only exception at the DREZ, where gaps are detected $(\boldsymbol{M}$, arrow). $\mathbf{O}, \boldsymbol{P}, \mathrm{Cxcr} 4 \mathrm{ISH}$ on E13.5 Cxcr4(fl/fl) $(\boldsymbol{O})$ and Wnt1-Cre:Cxcr4(fl/fl) $(\boldsymbol{P})$ spinal cord sections. The specificity of conditional knock-out of Cxcr4 is reconfirm to be in BC cells $(\boldsymbol{P}$, arrow) and dorsal Wnt1-positive domain $(\boldsymbol{P}$, arrowhead), but not in the VZ ventral to the Wnt1-positive domain. $\mathbf{Q}, \boldsymbol{R}$, Sox10 ISH on E13.5 (xcr4(fl/fl) (Q) and Wnt1-Cre:Cxcr4(f//fl) ( $\boldsymbol{R})$ spinal cord sections. No large-scale invasion of BC cells into

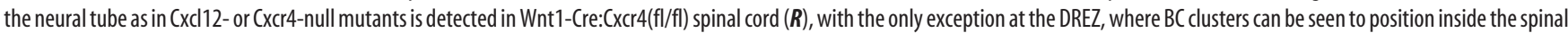
cord ( $\boldsymbol{R}$, arrow). Scale bars: $\boldsymbol{A}, \boldsymbol{B}, \boldsymbol{F}, \mathbf{G}, \boldsymbol{K}, \boldsymbol{M}, \mathbf{O}-\mathbf{Q}, \boldsymbol{R}, 200 \mu \mathrm{m} ; \boldsymbol{C}-\boldsymbol{E}$ and $\boldsymbol{H}-\boldsymbol{J}, 50 \mu \mathrm{m} ; \boldsymbol{L}, \mathbf{N}, 100 \mu \mathrm{m}$.

Proliferation and survival of neural progenitors are unaltered in Cxcr4/Cxcl12 knock-out mice

To investigate the causes that underlie the defects of radial glial scaffold in mice deficient in CXCL12 signaling, we first analyzed whether the proliferation and/or survival of the neural progenitors within the spinal cord VZ were affected in Cxcl12 or Cxcr4 mutants. To investigate cell proliferation, we examined the $\mathrm{S}$ phase and mitotic phase of the cell cycle of radial glia using BrdU incorporation and phosphorylated histone $\mathrm{H} 3 \mathrm{(pH} 3)$ antigenicity, respectively. Pregnant mothers from $\mathrm{Cxcr} 4^{+/-}$intercrosses were pulse labeled with BrdU at E12.5 and killed $2 \mathrm{~h}$ later. We found that there were no differences in the number and distribution of BrdU-positive or $\mathrm{pH} 3$-positive cells between the $\mathrm{Cxcr}^{-1-}$ and their wild-type littermates (data not shown). Apoptotic cell death was examined by immunohistochemistry against single-strand DNA, a hallmark of apoptotic cells. Again, the average number of apoptotic cells within the VZ per section showed no statistically significant differences between the
Cxcr4 ${ }^{-1-}$ and their wild-type littermates (data not shown). The lack of difference in cell proliferation and cell death between wild-type and a Cxcr4 mutant was also reported by Mithal et al. (2013) in spinal cords younger than E14. Therefore, these data suggest that causes other than reduced proliferation or enhanced cell death of neural progenitors underlie the defect in the radial glial scaffold in Cxcl2/Cxcr4-deficient mice.

CXCL12 signaling results in increased adhesiveness of radial glial cells to ECM components and activation of integrin $\beta 1$ Two aspects of radial glia development may affect the integrity of the radial glial scaffold: a morphological maturation of radial glia and adhesion between radial endfeet and the pial BM. We reasoned that CXCL12/CXCR4 is more likely to be involved in this latter aspect for the following reasons. First, the defects observed in the radial glial scaffold in the present study, which manifested primarily as gaps in pial endfeet and secondarily as mispositioned BC cells, occurred randomly and sporadically. Coincidently, de- 

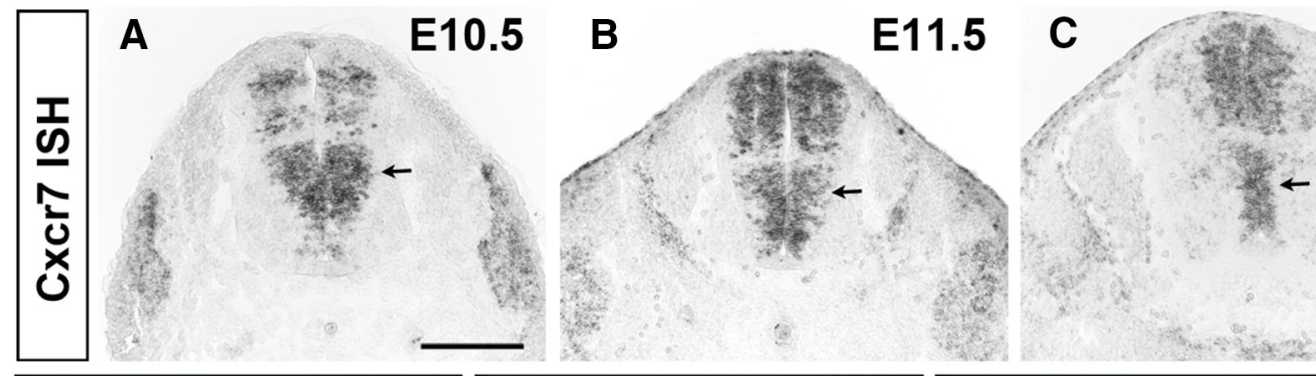

\section{E13.5}
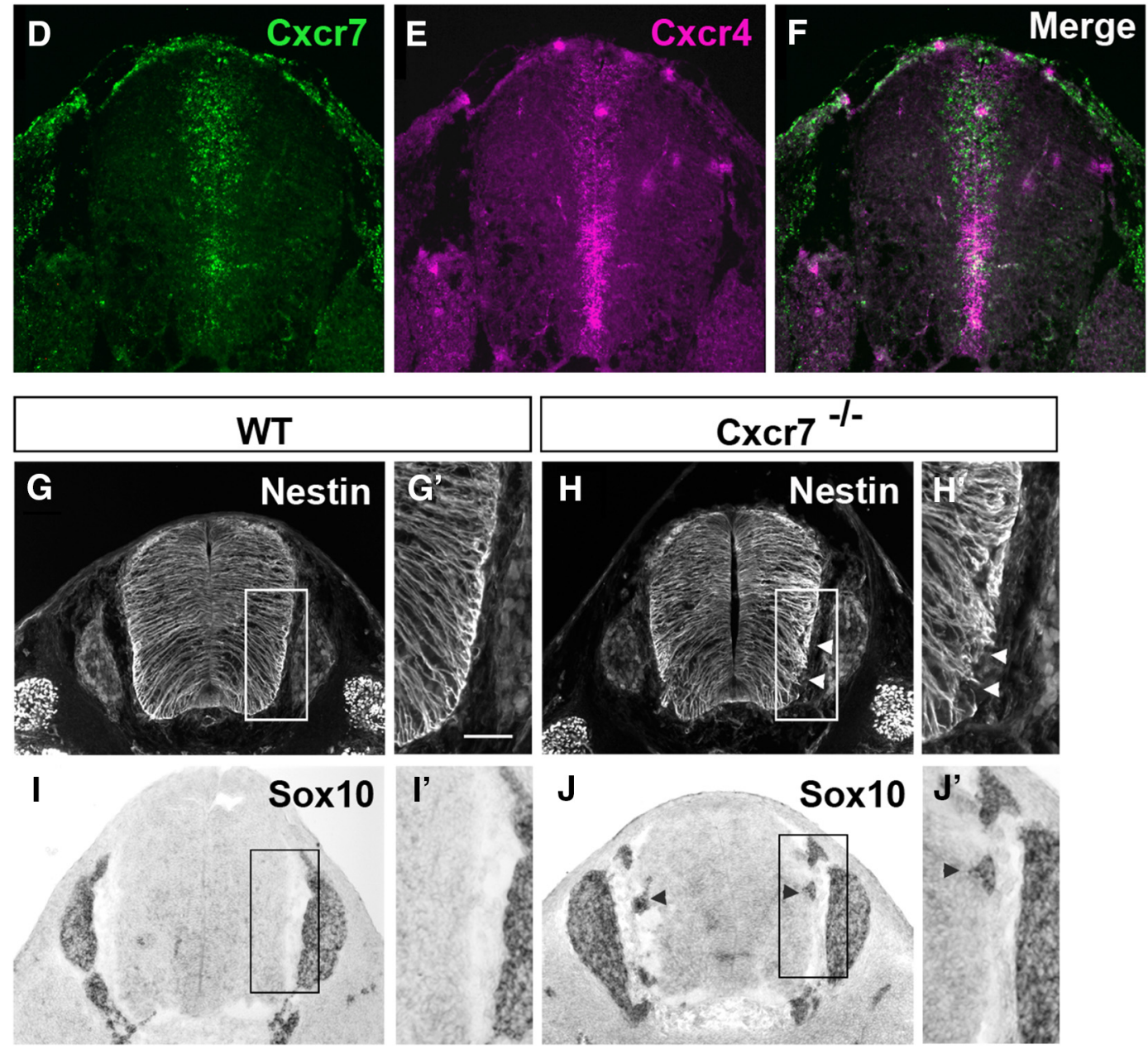

Figure 6. CXCR7 in spinal cord development. $\boldsymbol{A}-\boldsymbol{C}$, (XCr7 ISH on transverse sections of spinal cords at E10.5 (A), E11.5 (B), and E13.5 (C) show Cxcr7 expression in the spinal cord VZ at all these stages (arrows). D-F, Double fluorescence ISH on an E13.5 spinal cord section shows that CXcr7 (D) and Cxcr4 (E) mRNA are expressed in an overlapping and complementary manner within VZ. Merged image is shown in $\boldsymbol{F}$. $\boldsymbol{G}, \boldsymbol{H}$, Nestin immunohistochemistry on E13.5 spinal cord sections of the wild-type $(\boldsymbol{G})$ and $\left(\mathrm{xcr}\right.$-null mutant $(\boldsymbol{H})$. $\boldsymbol{G}^{\prime}$ and $\boldsymbol{H}^{\prime}$ are high-magnification views of the boxed areas in $\boldsymbol{G}$ and $\boldsymbol{H}$, respectively. The integrity of the radial glial scaffold is disrupted with gaps in the pial endfeet layer of the $\left(x c r 7\right.$-null mutant $\left(\boldsymbol{H}, \boldsymbol{H}^{\prime}\right.$, arrowheads). $\boldsymbol{I}, \boldsymbol{J}$, Sox 10 ISH on the wild-type $(I)$ and $\left(x c r 7\right.$-null mutant $(J) . I^{\prime}$ and $J^{\prime}$ are high-magnification views of the boxed areas in $I$ and $J$, respectively. Ectopic Sox10-positive cells are present within the spinal cords of $(x c r 7-n u l l$ mutant $\left(\boldsymbol{J}, \boldsymbol{J}^{\prime}\right.$, arrowheads). Scale bars: $200 \mu \mathrm{m}$ in all images, except $50 \mu \mathrm{m}$ in $\boldsymbol{G}^{\prime}, \boldsymbol{H}^{\prime}, \boldsymbol{I}^{\prime}, \boldsymbol{J}^{\prime}$.

fects observed in disrupted adhesion between radial endfeet and the pial BM in developing cortex also show a random appearance (Graus-Porta et al., 2001; Beggs et al., 2003; Niewmierzycka et al., 2005). Conversely, a defective maturation of radial morphology causes a general paucity of the radial glial scaffold (Anton et al., 1997; Hunter-Schaedle, 1997; Förster et al., 2002; Hartfuss et al., 2003; Yokota et al., 2009). Second, the proadhesive role of CXCL12 signaling is well established in migrating immune and cancerous cells and is thought to be achieved mainly by crosstalk with the integrin system (Kucia et al., 2004; Kinashi, 2005; Ley et al., 2007). We therefore hypothesized that CXCL12/CXCR4 signaling facilitates adhesion between the radial glia and the pial BM.
To explore this possibility, we first performed cell adhesion assays to test the adhesive strength of the dissociated radial glial cells to pial BM substrates. Spinal cords from $\mathrm{Tg}$ (Cxcr4-EGFP) were used for cell dissociation so that we could focus our analysis on CXCR4-expressing (EGFP-positive) radial glial cells. Dissociated E12.5 spinal cord cells with or without CXCL12 stimulation were plated on fibronectin or laminin, both of which have been shown to be abundant in the pial BM (Sheppard et al., 1991; Sievers et al., 1994; Sheppard et al., 1995; Timpl, 1996). Fibronectin was tested alone, whereas laminin was mixed with a small amount of poly-L-lysine due to poor coating otherwise. The percentage of GFP-positive cells that remained adhered after shaking the culture dish was used as an indicator of the strength of cell- 
A

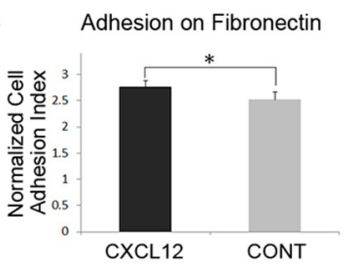

B

Adhesion on Laminin+PLL

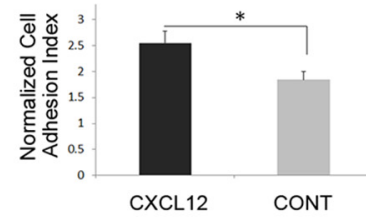

C

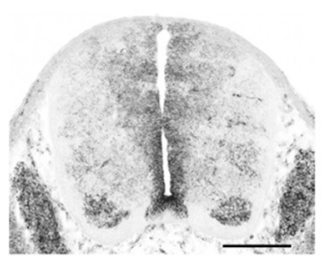

D
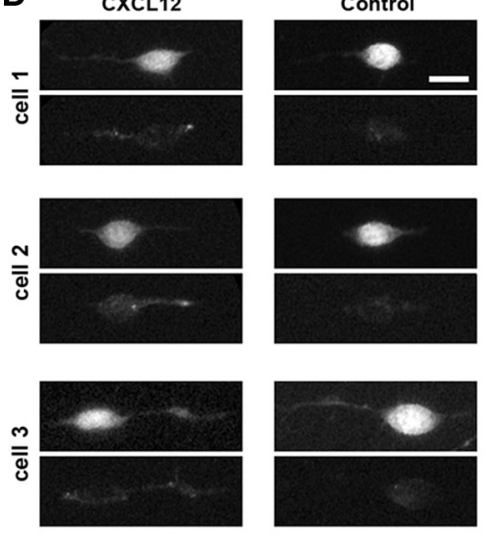

E

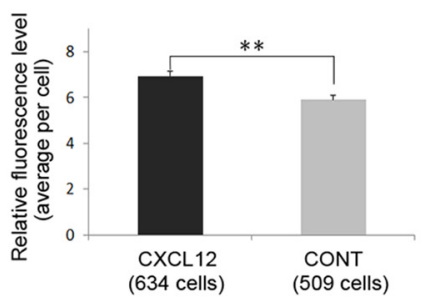

Control
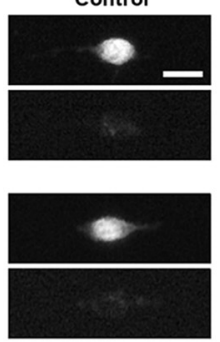

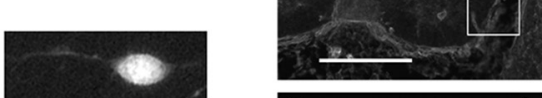

G

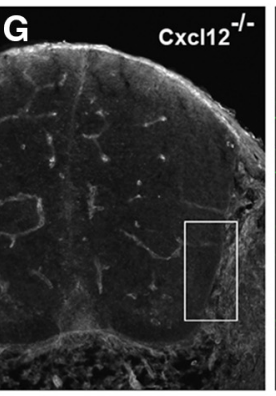

9EG7
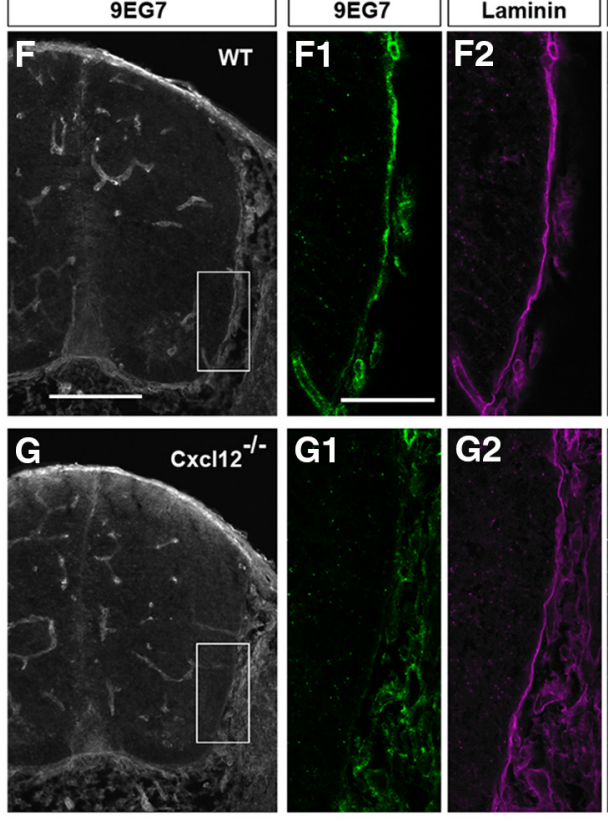

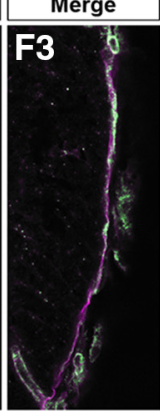

G3

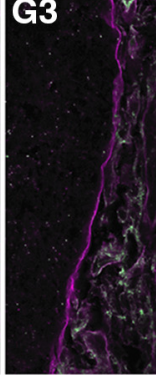

Figure 7. CXCL12 signaling enhances radial glia adhesion to pial BM substrates and activates integrin $\beta 1$. $\boldsymbol{A}, \boldsymbol{B}$, Histograms showing quantification of cell adhesion assays on two pial BM substrates, fibronectin $(\boldsymbol{A})$ and laminin (mixed with PLL) $(\boldsymbol{B})$. $\boldsymbol{A}$, GFP-positive cells were counted from 107 images of control and 114 images of CXCL12-stimulated conditions from five independent experiments. Normalized data were pooled and statistical analysis shows that CXCL12 stimulation causes a small but significant increase in adhesiveness to fibronectin compared with control $\left({ }^{*} p<\right.$ 0.05). $\boldsymbol{B}$, GFP-positive cells were counted from 22 images of control and 23 images of CXCL12-stimulated conditions from two independent experiments. Normalized data were pooled and statistical analysis shows that CXCL12 stimulation causes a small but significant increase in adhesiveness to laminin (mixed with PLL) compared with control ( ${ }^{*} p<0.05$ ). $C$, Integrin $\beta 1$ ISH on an E12.5 spinal cord section shows that integrin $\beta 1$ is expressed across the spinal cord VZ. D, Three representative cells from either control or CXCL12-stimulated cell populations after 9EG7 binding on living dissociated cells from E12.5 Tg(Cxcr4-EGFP)/ + spinal cord followed by immunostaining with a fluorescent secondary antibody. Top, GFP signal, which reports the expression of CXCR4 and outlines the cell morphology. Bottom, Signal of the 9EG7 integrin $\beta 1$ antibody. $\boldsymbol{E}$, Histogram showing quantitative levels of $9 \mathrm{EG} 7$ signals in cells under control and CXCL12-stimulated conditions. The $9 \mathrm{EG7}$ signal averaged over each cell's area was measured from 509 controls cells and 634 CXCL12-stimulated cells. Normalized data from four independent experiments were pooled. Statistical analysis showed a small but highly significant increase in the 9EG7 signal level in the CXCL12-stimulated population ( $\left.{ }^{* *} p<0.0005\right)$. $\boldsymbol{F}, \mathbf{G}, 9 \mathrm{EG} 7$ immunohistochemistry on fixed E13.5 wild-type $(\boldsymbol{F})$ and Cxcl12 knock-out (G) spinal cord sections. F1-F3 and G1-G3 are high-magnification views of the boxed areas in $\boldsymbol{F}$ and $\mathbf{G}$, respectively, showing separately $9 \mathrm{EG}$ (signal, the coimmunostained laminin signal to delineate the surface of the spinal cord, and the merged images. Very weak signals can be detected in the spinal cord VZ of both wild-type and Cxcl12 knock-out. In wild-type, $9 \mathrm{EG7}$ is detected in a thin layer overlying the surface of the spinal cord $(\boldsymbol{F})$ that is colocalized with the laminin-positive BM layer $(\boldsymbol{F} \mathbf{1}-\boldsymbol{F} \mathbf{3})$, suggesting that integrin $\beta 1$ is activated in the pial endfeet layer. In contrast, the $9 E G 7$ signal in the pial endfeet layer in the $\mathbf{C x c l 1 2 ^ { - 1 - }}$ spinal cord is much weaker, and disrupted (G, G1-G3). Scale bars: $\mathbf{C}, 200 \mu \mathrm{m} ; \boldsymbol{D}, 10 \mu \mathrm{m} ; \boldsymbol{F}, \mathbf{G}, 200 \mu \mathrm{m} ; \boldsymbol{F 1}-\mathbf{F 3}, \mathbf{G 1}-\mathbf{G 3}, 50$ $\mu \mathrm{m}$. Error bars in histograms indicate \pm SEM.

substrate adhesiveness. We detected a small but statistically significant increase of cell adhesiveness to fibronectin when cells were stimulated with recombinant CXCL12 (Fig. 7A). A similar result was also found on the laminin substrate (Fig. $7 B$ ). These data suggest that CXCL12 signaling increases the adhesiveness of radial glial cells to pial BM components.

Integrin $\alpha / \beta$ heterodimers are the main type of receptors for fibronectin, laminin, and several other BM components (Hynes, 2002; Yurchenco and Wadsworth, 2004). In addition, several lines of evidence have implicated integrin and integrin-mediated signaling in the regulation of adhesion between radial endfeet and the pial BM in the developing cortex (Georges-Labouesse et al., 1998; De Arcangelis et al., 1999; Graus-Porta et al., 2001; Beggs et al., 2003; Niewmierzycka et al., 2005; Belvindrah et al., 2007). We therefore hypothesized that CXCL12 signaling may activate integrin in radial glial cells, thereby increasing their adhesiveness to the pial BM. To test this possibility, we focused on integrins containing integrin $\beta 1$ for the following reasons. First, the integrin $\beta 1$ subfamily is highly expressed in the developing nervous system (Clegg et al., 2003) and, indeed, ISH showed that the integrin $\beta 1$ subunit was expressed across the spinal cord VZ at E12-E13 (Fig. 7C). Second, integrin $\beta 1$ is the shared $\beta$-type subunit that mediates binding to laminin and fibronectin (Hynes, 2002; Yurchenco and Wadsworth, 2004). Third, CXCL12/CXCR4 sig- naling has been shown to crosstalk to and activate integrin $\beta 1$ in immune and cancerous cells (Peled et al., 2000; Parmo-Cabañas et al., 2004; Hartmann et al., 2005; Jones et al., 2007; Petty et al., 2009). Last, integrin- $\beta 1$-deficient mice show a disrupted radial glial scaffold in the developing cortex, a defect thought due to compromised adhesiveness between basal processes and the pial BM (Graus-Porta et al., 2001; Belvindrah et al., 2007). To evaluate the status of activated integrin $\beta 1$, we used an integrin antibody, clone 9EG7, which recognizes an epitope only exposed on the extracellular domain of the activated integrin $\beta 1$ (Lenter et al., 1993; Bazzoni et al., 1995). We first performed 9EG7 binding on living radial glial cells dissociated from $\mathrm{Tg}(\mathrm{Cxcr} 4$-EGFP) spinal cords with or without prior stimulation of CXCL12. The amount of cell surface binding of 9EG7 was then evaluated after secondary antibody staining and quantitative fluorescence immunohistochemistry. CXCL12 stimulation increased the level of 9EG7 antigenicity compared with control, indicating an increase in the active form of integrin $\beta 1$ (Fig. $7 D, E$ ). We then performed 9EG7 immunohistochemistry directly on tissue sections from $\mathrm{Cxcl} 12^{-1-}$ and wild-type spinal cords because it has been shown previously that 9EG7 binding can be used to reflect the activated state of integrin $\beta 1$ on fixed tissues (Daley et al., 2011). Despite the dominating 9EG7 signal in blood vessels in and around the neural tube and the mesenchyme, we could discern a weak signal 
in the spinal cord VZ of both genotypes (Fig. $7 F, G$ ). In the wildtype spinal cord, we detected a 9EG7 signal as a discrete line along the spinal cord surface (Fig. $7 F$ ), which appeared to colocalize with the laminin-positive BM (Fig. $7 F 1, F 2, F 3$ ), suggesting the abundance of activated integrin $\beta 1$ in the pial endfeet layer. In Cxcl12 ${ }^{-1-}$, however, the 9EG7 signal in the pial endfeet layer was markedly weakened (Fig. 7G,G1,G2,G3), suggesting a reduction of 9EG7 activation in the pial endfeet in Cxcl12 $2^{-1-}$ spinal cords. The in vitro and in vivo experiments presented here complement each other and support the notion that CXCL12 signaling activates integrin $\beta 1$ in spinal radial glia.

Together, these results show that CXCL12/CXCR4 downstream signaling within the radial glial cells facilitates the adhesiveness of these cells to the pial BM components, which is likely to be achieved at least in part by the ability of CXCL12 signaling to activate integrin $\beta 1$.

\section{Discussion}

In this study, we have demonstrated that CXCL12/CXCR4 signaling plays a cell autonomous role in maintaining the integrity of the radial glial scaffold during spinal cord development. The signaling serves this function, at least in part, by facilitating the adhesion of radial glia to the pial $\mathrm{BM}$, probably via activation of integrin $\beta 1$. Gaps in the radial glial scaffold due to defective CXCL12 signaling further causes an invasion of BC cells into the neural tube. Our study implicates the necessity of maintaining the integrity of the radial glial scaffold to safeguard a healthy CNS/PNS boundary and unravels a novel molecular mechanism that involves chemokine signaling in helping to achieve this at the spinal cord level.

\section{CXCR4 expression in BC cells}

$\mathrm{BC}$ cells are derived from ventrally migrating neural crest and become selectively arrested at the DREZ and MEP (Niederländer and Lumsden, 1996; Golding and Cohen, 1997). These cells play dual functions in keeping motor neuron somas within the CNS (Vermeren et al., 2003) and constitute a source of neural stem cells that contributes neurons and glia to the PNS (Maro et al., 2004; Hjerling-Leffler et al., 2005). Conditional Cxcr4 knock-out in $\mathrm{BC}$ cells does not affect the initial formation of BC clusters at the DREZ and MEP, suggesting the initial migration, specification, and arrest at the DREZ and MEP do not require CXCL12/ CXCR4 signaling. It is possible that CXCR4 expression in BC cells contributes to the stem cell properties of BC cells. Initial tests with Ki67 and CXCR4 double immunohistochemistry showed that the percentage of proliferating (Ki67-positive) among total BC cells (CXCR4-positive) at the DREZ was comparable between wild-type (90.76 $\pm 2.09 \%)$ and Cxcl12 mutant (88.92 $\pm 2.37 \%)$ mice, suggesting that CXCL12/CXCR4 signaling is not required for BC cell proliferation. Whether CXCL12/CXCR4 regulates the self-renewal, range of multipotency, differentiation, and progeny migration of $\mathrm{BC}$ cells is of future interest.

\section{Primary function of CXCL12/CXCR4 in radial glia development and the underlying mechanisms}

The present study and others have demonstrated the expression of CXCR4 in radial glia (Stumm et al., 2007; Mithal et al., 2013). Our data suggest that CXCL12/CXCR4 play a primary function in radial glia, whereas the mispositioning of $\mathrm{BC}$ cells is a secondary defect. This conclusion is mainly drawn from analysis of the radial-glia-specific Cxcr4 conditional knock-out mice. In support of our conclusion, Mithal et al. (2013) also reported recently the expression of CXCR4 in spinal cord radial glia and a disrupted radial glial scaffold in a Cxcr4 conditional knock-out. However, that study did not investigate the consequences of the defective radial glial scaffold nor the underlying mechanisms. In addition, using a Cxcr7-EGFP reporter line, Mithal et al. (2013) concluded that CXCR7 is not expressed in spinal cord radial glia. In contrast, we show clearly that Cxcr7 is expressed in the spinal cord VZ by in situ hybridization and, more importantly, we demonstrate that Cxcr7 mutants have similar albeit milder phenotype to Cxcl12/ Cxcr4 mutants. The precise function of CXCR7 in spinal cord radial glia remains ambiguous at present. It may act as a signaling receptor either independently or cooperatively with CXCR4. It is also possible that CXCR7 serves as a scavenger receptor to sequester CXCL12 to prevent excessive CXCL12-mediated CXCR4 downregulation via endocytosis, similar to what has been demonstrated for CXCR7 in the migration of the cortical interneurons (Abe et al., 2014).

Here, we provide evidence showing that CXCL12 stimulation increases radial glia adhesiveness to $\mathrm{BM}$ components and that it activates integrin $\beta 1$, although we cannot completely rule out a possible involvement of CXCL12 signaling in promoting the morphological maturation of radial glia, for example, by affecting the reelin or notch pathways indirectly. However, we do not think it likely that CXCL12 affects reelin pathway, because both the reelin effector DAB1 and a radial glia phenotype in the reeler spinal cord appear to localize to MEP (Lee and Song, 2013). Therefore, drawing from our current data, we think a plausible in vivo scenario is that CXCL12 secreted from pial meninges signals through CXCR4 receptors at pial endfeet, which in turn facilitates radial endfeet adhesion to the pial BM via activation of integrin $\beta 1$. This enhanced adhesion would help radial processes remain attached to the pial BM when the neuroepithelium expands rapidly. Mithal et al. (2013) showed that CXCL12-mRFP fusion protein expressed from a BAC transgenic line is associated with and ingested by the pial endfeet of spinal radial glia, indicating that signaling events could take place locally at this subcellular region. The activation of integrin $\beta 1$ by CXCL12 is most likely via insideout signaling, in which the avidity of the integrin heterodimer is enhanced by intracellular signaling pathways affecting the intracellular domain of integrin $\beta$ (Ginsberg et al., 2005; Moser et al., 2009). Heterotrimeric Gi protein downstream of CXCL12 signaling is capable of inducing such inside-out signaling via a variety of effectors, including Rap1, Dock2, PI3K, and RhoA (Kinashi, 2005; Ley et al., 2007). Whether any of these effectors regulates the maintenance of the integrity of the radial glial scaffold in the spinal cord requires further study.

The present study suggests that CXCL12 is a meningesderived extrinsic signal that regulates the adhesive signaling within radial glia to ensure the continuous adhesion of their endfeet to the pial BM at the spinal cord level. Do such meninges-derived extrinsic signals also operate in other CNS regions, for example, the neocortex? CXCR4 expression was not detected in the $\mathrm{VZ}$ of the cortex during the period of neurogenesis (Y.Z., unpublished observations; López-Bendito et al., 2008); therefore, CXCL12/CXCR4 signaling is unlikely to be involved in the development of the cortical radial glia. However, meninges are a rich source of other signaling molecules, including TGF- $\beta 1$ (Flanders et al., 1991), BMP7 (Segklia et al., 2012), and Wnt5a (Hayashi et al., 2008). Although the function of these meninges-derived signals have been little explored, it is conceivable that some of them may crosstalk to adhesive signaling in radial glial cells. 


\section{Maintaining CNS/PNS boundary in developing spinal cord} How cellular mixing is prevented at the DREZ and MEP without the pial $\mathrm{BM}$ is a special issue concerning the spinal cord (and the hindbrain). In the mature spinal cord, the apposition of glia limitans from astrocyte processes in the CNS and Schwann cells in the PNS defines the CNS/PNS interface at the DREZ and MEP (Fraher, 1997; Golding et al., 1997; Fraher, 2002). During development, $\mathrm{BC}$ cells at the MEP were shown to keep motor neurons within the spinal cord (Vermeren et al., 2003). We demonstrate here that radial glial processes and their endfeet contribute to preventing cellular mixing at the DREZ and MEP by keeping BC cells out. This role of radial glia is further supported by a recent study showing that an intact radial glial scaffold in the ventral spinal cord helps to confine motor neurons within the spinal cord (Lee and Song, 2013).

We suspect that ectopic $\mathrm{BC}$ cells probably enter the spinal cord from the DREZ and MEP because the pial BM elsewhere remains intact in mutants (Fig. 3). The DREZ might be the main entrance for the invasion because these ectopic BC cells express a high level of CXCR4 similar to BC cells at the DREZ. We envisage that, under normal conditions, the dense endfeet from fully extended radial processes terminate onto the pial $\mathrm{BM}$ that encircles the DREZ and the BC cells (Y.Z., unpublished observations) to deny entry of the BC cells into the neural tube. In Cxcl12/Cxcr4 mutants, retraction of some radial processes around the DREZ allowed some BC cells to move in. Such localized invasion could be seen in Wnt1-Cre-mediated conditional knock-out mice, in which Cxcr4 was depleted only from the dorsal VZ domain. The additional gaps in the radial endfeet layer ventral to the DREZ then invited further BC cell invasion. Exactly what signals induce this further invasion remains highly speculative. One possibility is that the retraction of radial processes from adhesions on the pial BM might cause debris of the pial BM, radial endfeet and their cytoplasmic content to disperse into the environment, akin to a localized mild lesion. Lesion-induced molecular and cellular consequences may attract $\mathrm{BC}$ cells, which are highly migratory neural crest stem cells. The preferential migration of neural stem cells toward sites of lesions and pathology has been shown in the postnatal neural system (Arvidsson et al., 2002; Müller et al., 2006). In addition, when isolated $B C$ cells were transplanted into demyelinated spinal cord, they migrated toward the lesion site and differentiated mainly into myelin-forming Schwann cells (Zujovic et al., 2010). It should be noted, however, that the invasion of $\mathrm{BC}$ cells is severe at the lumbosacral level but rare at the rostral spinal cord despite the presence of radial glia defects there. This might be due to the temporal gradient of the maturation of spinal cord along its rostrocaudal axis. Therefore, when defects in the radial glial scaffold begin to emerge, $\mathrm{BC}$ cells at the rostral spinal cord might already form tightly associated clusters at nerve roots, whereas those at the caudal spinal cord might still be loose and highly mobile, making them more susceptible to respond to disturbances from within the neural tube. We speculate that mispositioning of $\mathrm{BC}$ cells within the CNS may cause a reduction of cellular components of the DRG and dorsal/ventral roots because the displaced BC cells should have difficulty in supplying neurons and glia to these PNS structures. Although this possibility was not tested directly in the present study, Cxcr4-null mice indeed have smaller and malformed DRG, which, interestingly, appeared to be more severe at the caudal spinal cord (Belmadani et al., 2005).

\section{References}

Abe P, Mueller W, Schütz D, MacKay F, Thelen M, Zhang P, Stumm R (2014) CXCR7 prevents excessive CXCL12-mediated downregulation of
CXCR4 in migrating cortical interneurons. Development 141:1857-1863. CrossRef Medline

Altman J, Bayer SA (1984) The development of the rat spinal cord. Adv Anat Embryol Cell Biol 85:1-164. CrossRef Medline

Anthony TE, Klein C, Fishell G, Heintz N (2004) Radial glia serve as neuronal progenitors in all regions of the central nervous system. Neuron 41: 881-890. CrossRef Medline

Anton ES, Marchionni MA, Lee KF, Rakic P (1997) Role of GGF/neuregulin signaling in interactions between migrating neurons and radial glia in the developing cerebral cortex. Development 124:3501-3510. Medline

Arvidsson A, Collin T, Kirik D, Kokaia Z, Lindvall O (2002) Neuronal replacement from endogenous precursors in the adult brain after stroke. Nat Med 8:963-970. CrossRef Medline

Balabanian K, Lagane B, Infantino S, Chow KY, Harriague J, Moepps B, Arenzana-Seisdedos F, Thelen M, Bachelerie F (2005) The chemokine SDF-1/CXCL12 binds to and signals through the orphan receptor RDC1 in T lymphocytes. J Biol Chem 280:35760-35766. CrossRef Medline

Bazzoni G, Shih DT, Buck CA, Hemler ME (1995) Monoclonal antibody 9EG7 defines a novel beta 1 integrin epitope induced by soluble ligand and manganese, but inhibited by calcium. J Biol Chem 270:25570-25577. CrossRef Medline

Beggs HE, Schahin-Reed D, Zang K, Goebbels S, Nave KA, Gorski J, Jones KR, Sretavan D, Reichardt LF (2003) FAK deficiency in cells contributing to the basal lamina results in cortical abnormalities resembling congenital muscular dystrophies. Neuron 40:501-514. CrossRef Medline

Belmadani A, Tran PB, Ren D, Assimacopoulos S, Grove EA, Miller RJ (2005) The chemokine stromal cell-derived factor-1 regulates the migration of sensory neuron progenitors. J Neurosci 25:3995-4003. CrossRef Medline

Belvindrah R, Graus-Porta D, Goebbels S, Nave KA, Müller U (2007) Beta1 integrins in radial glia but not in migrating neurons are essential for the formation of cell layers in the cerebral cortex. J Neurosci 27:13854-13865. CrossRef Medline

Britsch S, Goerich DE, Riethmacher D, Peirano RI, Rossner M, Nave KA, Birchmeier C, Wegner M (2001) The transcription factor Sox10 is a key regulator of peripheral glial development. Genes Dev 15:66-78. CrossRef Medline

Burns JM, Summers BC, Wang Y, Melikian A, Berahovich R, Miao Z, Penfold ME, Sunshine MJ, Littman DR, Kuo CJ, Wei K, McMaster BE, Wright K, Howard MC, Schall TJ (2006) A novel chemokine receptor for SDF-1 and I-TAC involved in cell survival, cell adhesion, and tumor development. J Exp Med 203:2201-2213. CrossRef Medline

Charron F, Stein E, Jeong J, McMahon AP, Tessier-Lavigne M (2003) The morphogen sonic hedgehog is an axonal chemoattractant that collaborates with netrin-1 in midline axon guidance. Cell 113:11-23. CrossRef Medline

Clegg DO, Wingerd KL, Hikita ST, Tolhurst EC (2003) Integrins in the development, function and dysfunction of the nervous system. Front Biosci 8:d723-750. CrossRef Medline

Daley WP, Kohn JM, Larsen M (2011) A focal adhesion protein-based mechanochemical checkpoint regulates cleft progression during branching morphogenesis. Dev Dyn 240:2069-2083. CrossRef Medline

Danielian PS, Muccino D, Rowitch DH, Michael SK, McMahon AP (1998) Modification of gene activity in mouse embryos in utero by a tamoxifeninducible form of Cre recombinase. Curr Biol 8:1323-1326. CrossRef Medline

De Arcangelis A, Mark M, Kreidberg J, Sorokin L, Georges-Labouesse E (1999) Synergistic activities of alpha3 and alpha6 integrins are required during apical ectodermal ridge formation and organogenesis in the mouse. Development 126:3957-3968. Medline

Flanders KC, Lüdecke G, Engels S, Cissel DS, Roberts AB, Kondaiah P, Lafyatis R, Sporn MB, Unsicker K (1991) Localization and actions of transforming growth factor-beta $s$ in the embryonic nervous system. Development 113:183-191. Medline

Förster E, Tielsch A, Saum B, Weiss KH, Johanssen C, Graus-Porta D, Müller U, Frotscher M (2002) Reelin, Disabled 1, and beta 1 integrins are required for the formation of the radial glial scaffold in the hippocampus. Proc Natl Acad Sci U S A 99:13178-13183. CrossRef Medline

Fraher J (2002) Axons and glial interfaces: ultrastructural studies. J Anat 200:415-430. CrossRef Medline

Fraher JP (1997) Axon-glial relationships in early CNS-PNS transitional 
zone development: an ultrastructural study. J Neurocytol 26:41-52. CrossRef Medline

Georges-Labouesse E, Mark M, Messaddeq N, Gansmüller A (1998) Essential role of alpha 6 integrins in cortical and retinal lamination. Curr Biol 8:983-986. CrossRef Medline

Ginsberg MH, Partridge A, Shattil SJ (2005) Integrin regulation. Curr Opin Cell Biol 17:509-516. CrossRef Medline

Golding JP, Cohen J (1997) Border controls at the mammalian spinal cord: late-surviving neural crest boundary cap cells at dorsal root entry sites may regulate sensory afferent ingrowth and entry zone morphogenesis. Mol Cell Neurosci 9:381-396. CrossRef Medline

Golding J, Shewan D, Cohen J (1997) Maturation of the mammalian dorsal root entry zone-from entry to no entry. Trends Neurosci 20:303-308. CrossRef Medline

Gong S, Zheng C, Doughty ML, Losos K, Didkovsky N, Schambra UB, Nowak NJ, Joyner A, Leblanc G, Hatten ME, Heintz N (2003) A gene expression atlas of the central nervous system based on bacterial artificial chromosomes. Nature 425:917-925. CrossRef Medline

Graus-Porta D, Blaess S, Senften M, Littlewood-Evans A, Damsky C, Huang Z, Orban P, Klein R, Schittny JC, Müller U (2001) Beta1-class integrins regulate the development of laminae and folia in the cerebral and cerebellar cortex. Neuron 31:367-379. CrossRef Medline

Halfter W, Dong S, Yip YP, Willem M, Mayer U (2002) A critical function of the pial basement membrane in cortical histogenesis. J Neurosci 22:60296040. Medline

Hari L, Miescher I, Shakhova O, Suter U, Chin L, Taketo M, Richardson WD, Kessaris N, Sommer L (2012) Temporal control of neural crest lineage generation by $\mathrm{Wnt} / \beta$-catenin signaling. Development 139:2107-2117. CrossRef Medline

Hartfuss E, Förster E, Bock HH, Hack MA, Leprince P, Luque JM, Herz J, Frotscher M, Götz M (2003) Reelin signaling directly affects radial glia morphology and biochemical maturation. Development 130:4597-4609. CrossRef Medline

Hartmann TN, Burger JA, Glodek A, Fujii N, Burger M (2005) CXCR4 chemokine receptor and integrin signaling co-operate in mediating adhesion and chemoresistance in small cell lung cancer (SCLC) cells. Oncogene 24:4462-4471. CrossRef Medline

Hasegawa H, Ashigaki S, Takamatsu M, Suzuki-Migishima R, Ohbayashi N, Itoh N, Takada S, Tanabe Y (2004) Laminar patterning in the developing neocortex by temporally coordinated fibroblast growth factor signaling. J Neurosci 24:8711-8719. CrossRef Medline

Hayashi H, Morizane A, Koyanagi M, Ono Y, Sasai Y, Hashimoto N, Takahashi J (2008) Meningeal cells induce dopaminergic neurons from embryonic stem cells. Eur J Neurosci 27:261-268. CrossRef Medline

Hjerling-Leffler J, Marmigère F, Heglind M, Cederberg A, Koltzenburg M, Enerbäck S, Ernfors P (2005) The boundary cap: a source of neural crest stem cells that generate multiple sensory neuron subtypes. Development 132:2623-2632. CrossRef Medline

Hockfield S, McKay RD (1985) Identification of major cell classes in the developing mammalian nervous system. J Neurosci 5:3310-3328. Medline

Hunter-Schaedle KE (1997) Radial glial cell development and transformation are disturbed in reeler forebrain. J Neurobiol 33:459-472. Medline

Hynes RO (2002) Integrins: bidirectional, allosteric signaling machines. Cell 110:673-687. CrossRef Medline

Imayoshi I, Ohtsuka T, Metzger D, Chambon P, Kageyama R (2006) Temporal regulation of Cre recombinase activity in neural stem cells. Genesis 44:233-238. CrossRef Medline

Jiang X, Rowitch DH, Soriano P, McMahon AP, Sucov HM (2000) Fate of the mammalian cardiac neural crest. Development 127:1607-1616. Medline

Jones J, Marian D, Weich E, Engl T, Wedel S, Relja B, Jonas D, Blaheta RA (2007) CXCR4 chemokine receptor engagement modifies integrin dependent adhesion of renal carcinoma cells. Exp Cell Res 313:4051-4065. CrossRef Medline

Kinashi T (2005) Intracellular signalling controlling integrin activation in lymphocytes. Nat Rev Immunol 5:546-559. CrossRef Medline

Kucia M, Jankowski K, Reca R, Wysoczynski M, Bandura L, Allendorf DJ, Zhang J, Ratajczak J, Ratajczak MZ (2004) CXCR4-SDF-1 signalling, locomotion, chemotaxis and adhesion. J Mol Histol 35:233-245. Medline Kuhlbrodt K, Herbarth B, Sock E, Hermans-Borgmeyer I, Wegner M (1998)
Sox10, a novel transcriptional modulator in glial cells. J Neurosci 18:237250. Medline

Lee H, Song MR (2013) The structural role of radial glial endfeet in confining spinal motor neuron somata is controlled by the Reelin and Notch pathways. Exp Neurol 249:83-94. CrossRef Medline

Lendahl U, Zimmerman LB, McKay RD (1990) CNS stem cells express a new class of intermediate filament protein. Cell 60:585-595. CrossRef Medline

Lenter M, Uhlig H, Hamann A, Jenö P, Imhof B, Vestweber D (1993) A monoclonal antibody against an activation epitope on mouse integrin chain beta 1 blocks adhesion of lymphocytes to the endothelial integrin alpha 6 beta 1. Proc Natl Acad Sci U S A 90:9051-9055. CrossRef Medline

Ley K, Laudanna C, Cybulsky MI, Nourshargh S (2007) Getting to the site of inflammation: the leukocyte adhesion cascade updated. Nat Rev Immunol 7:678-689. CrossRef Medline

Lieberam I, Agalliu D, Nagasawa T, Ericson J, Jessell TM (2005) A Cxcl12CXCR4 chemokine signaling pathway defines the initial trajectory of mammalian motor axons. Neuron 47:667-679. CrossRef Medline

López-Bendito G, Sánchez-Alcañiz JA, Pla R, Borrell V, Picó E, Valdeolmillos M, Marín O (2008) Chemokine signaling controls intracortical migration and final distribution of GABAergic interneurons. J Neurosci 28 : 1613-1624. CrossRef Medline

Maro GS, Vermeren M, Voiculescu O, Melton L, Cohen J, Charnay P, Topilko P (2004) Neural crest boundary cap cells constitute a source of neuronal and glial cells of the PNS. Nat Neurosci 7:930-938. CrossRef Medline

McDermott KW, Barry DS, McMahon SS (2005) Role of radial glia in cytogenesis, patterning and boundary formation in the developing spinal cord. J Anat 207:241-250. CrossRef Medline

Meyer D, Birchmeier C (1995) Multiple essential functions of neuregulin in development. Nature 378:386-390. CrossRef Medline

Misson JP, Edwards MA, Yamamoto M, Caviness VS Jr (1988) Identification of radial glial cells within the developing murine central nervous system: studies based upon a new immunohistochemical marker. Brain Res Dev Brain Res 44:95-108. CrossRef Medline

Mithal DS, Ren D, Miller RJ (2013) CXCR4 signaling regulates radial glial morphology and cell fate during embryonic spinal cord development. Glia 61:1288-1305. CrossRef Medline

Moore SA, Saito F, Chen J, Michele DE, Henry MD, Messing A, Cohn RD, Ross-Barta SE, Westra S, Williamson RA, Hoshi T, Campbell KP (2002) Deletion of brain dystroglycan recapitulates aspects of congenital muscular dystrophy. Nature 418:422-425. CrossRef Medline

Moser M, Legate KR, Zent R, Fässler R (2009) The tail of integrins, talin, and kindlins. Science 324:895-899. CrossRef Medline

Müller FJ, Snyder EY, Loring JF (2006) Gene therapy: can neural stem cells deliver? Nat Rev Neurosci 7:75-84. CrossRef Medline

Myshrall TD, Moore SA, Ostendorf AP, Satz JS, Kowalczyk T, Nguyen H, Daza RA, Lau C, Campbell KP, Hevner RF (2012) Dystroglycan on radial glia end feet is required for pial basement membrane integrity and columnar organization of the developing cerebral cortex. J Neuropathol Exp Neurol 71:1047-1063. CrossRef Medline

Nagasawa T, Hirota S, Tachibana K, Takakura N, Nishikawa S, Kitamura Y, Yoshida N, Kikutani H, Kishimoto T (1996) Defects of B-cell lymphopoiesis and bone-marrow myelopoiesis in mice lacking the CXC chemokine PBSF/SDF-1. Nature 382:635-638. CrossRef Medline

Niederländer C, Lumsden A (1996) Late emigrating neural crest cells migrate specifically to the exit points of cranial branchiomotor nerves. Development 122:2367-2374. Medline

Niewmierzycka A, Mills J, St-Arnaud R, Dedhar S, Reichardt LF (2005) Integrin-linked kinase deletion from mouse cortex results in cortical lamination defects resembling cobblestone lissencephaly. J Neurosci 25: 7022-7031. CrossRef Medline

Novak A, Guo C, Yang W, Nagy A, Lobe CG (2000) Z/EG, a double reporter mouse line that expresses enhanced green fluorescent protein upon Cremediated excision. Genesis 28:147-155. Medline

Parmo-Cabañas M, Bartolomé RA, Wright N, Hidalgo A, Drager AM, Teixidó J (2004) Integrin alpha4beta1 involvement in stromal cell-derived factor-1alpha-promoted myeloma cell transendothelial migration and adhesion: role of cAMP and the actin cytoskeleton in adhesion. Exp Cell Res 294:571-580. CrossRef Medline

Peled A, Kollet O, Ponomaryov T, Petit I, Franitza S, Grabovsky V, Slav MM, Nagler A, Lider O, Alon R, Zipori D, Lapidot T (2000) The chemokine SDF-1 activates the integrins LFA-1, VLA-4, and VLA-5 on immature 
human CD34(+) cells: role in transendothelial/stromal migration and engraftment of NOD/SCID mice. Blood 95:3289-3296. Medline

Petty JM, Lenox CC, Weiss DJ, Poynter ME, Suratt BT (2009) Crosstalk between CXCR4/stromal derived factor-1 and VLA-4/VCAM-1 pathways regulates neutrophil retention in the bone marrow. J Immunol 182:604612. CrossRef Medline

Rakic P (1972) Mode of cell migration to the superficial layers of fetal monkey neocortex. J Comp Neurol 145:61-83. CrossRef Medline

Rakic P (2003) Elusive radial glial cells: historical and evolutionary perspective. Glia 43:19-32. CrossRef Medline

Schneider-Maunoury S, Topilko P, Seitandou T, Levi G, Cohen-Tannoudji M, Pournin S, Babinet C, Charnay P (1993) Disruption of Krox-20 results in alteration of rhombomeres 3 and 5 in the developing hindbrain. Cell 75:1199-1214. CrossRef Medline

Segklia A, Seuntjens E, Elkouris M, Tsalavos S, Stappers E, Mitsiadis TA, Huylebroeck D, Remboutsika E, Graf D (2012) Bmp7 regulates the survival, proliferation, and neurogenic properties of neural progenitors cells during corticogenesis in the mouse. PLoS One 7:e34088. CrossRef Medline

Sheppard AM, Hamilton SK, Pearlman AL (1991) Changes in the distribution of extracellular matrix components accompany early morphogenetic events of mammalian cortical development. J Neurosci 11:3928-3942. Medline

Sheppard AM, Brunstrom JE, Thornton TN, Gerfen RW, Broekelmann TJ, McDonald JA, Pearlman AL (1995) Neuronal production of fibronectin in the cerebral cortex during migration and layer formation is unique to specific cortical domains. Dev Biol 172:504-518. CrossRef Medline

Sierro F, Biben C, Martínez-Muñoz L, Mellado M, Ransohoff RM, Li M, Woehl B, Leung H, Groom J, Batten M, Harvey RP, Martínez-A C, Mackay CR, Mackay F (2007) Disrupted cardiac development but normal hematopoiesis in mice deficient in the second CXCL12/SDF-1 receptor, CXCR7. Proc Natl Acad Sci U S A 104:14759-14764. CrossRef Medline

Sievers J, Pehlemann FW, Gude S, Berry M (1994) Meningeal cells organize the superficial glia limitans of the cerebellum and produce components of both the interstitial matrix and the basement membrane. J Neurocytol 23:135-149. CrossRef Medline

Stumm R, Kolodziej A, Schulz S, Kohtz JD, Höllt V (2007) Patterns of SDFlalpha and SDF-1gamma mRNAs, migration pathways, and phenotypes of CXCR4-expressing neurons in the developing rat telencephalon. J Comp Neurol 502:382-399. CrossRef Medline

Tachibana K, Hirota S, Iizasa H, Yoshida H, Kawabata K, Kataoka Y, Kitamura Y, Matsushima K, Yoshida N, Nishikawa S, Kishimoto T, Nagasawa $\mathrm{T}$ (1998) The chemokine receptor CXCR4 is essential for vascularization of the gastrointestinal tract. Nature 393:591-594. CrossRef Medline

Timpl R (1996) Macromolecular organization of basement membranes. Curr Opin Cell Biol 8:618-624. CrossRef Medline
Timpl R, Brown JC (1996) Supramolecular assembly of basement membranes. Bioessays 18:123-132. CrossRef Medline

Tokoyoda K, Egawa T, Sugiyama T, Choi BI, Nagasawa T (2004) Cellular niches controlling B lymphocyte behavior within bone marrow during development. Immunity 20:707-718. CrossRef Medline

Topilko P, Schneider-Maunoury S, Levi G, Baron-Van Evercooren A, Chennoufi AB, Seitanidou T, Babinet C, Charnay P (1994) Krox-20 controls myelination in the peripheral nervous system. Nature 371:796-799. CrossRef Medline

Tran PB, Banisadr G, Ren D, Chenn A, Miller RJ (2007) Chemokine receptor expression by neural progenitor cells in neurogenic regions of mouse brain. J Comp Neurol 500:1007-1033. CrossRef Medline

Vermeren M, Maro GS, Bron R, McGonnell IM, Charnay P, Topilko P, Cohen J (2003) Integrity of developing spinal motor columns is regulated by neural crest derivatives at motor exit points. Neuron 37:403-415. CrossRef Medline

Wilkinson DG, Bhatt S, Chavrier P, Bravo R, Charnay P (1989) Segmentspecific expression of a zinc-finger gene in the developing nervous system of the mouse. Nature 337:461-464. CrossRef Medline

Yokota Y, Kim WY, Chen Y, Wang X, Stanco A, Komuro Y, Snider W, Anton ES (2009) The adenomatous polyposis coli protein is an essential regulator of radial glial polarity and construction of the cerebral cortex. Neuron 61:42-56. CrossRef Medline

Yurchenco PD, Wadsworth WG (2004) Assembly and tissue functions of early embryonic laminins and netrins. Curr Opin Cell Biol 16:572-579. CrossRef Medline

Zarbalis K, Siegenthaler JA, Choe Y, May SR, Peterson AS, Pleasure SJ (2007) Cortical dysplasia and skull defects in mice with a Foxcl allele reveal the role of meningeal differentiation in regulating cortical development. Proc Natl Acad Sci U S A 104:14002-14007. CrossRef Medline

Zhu Y, Murakami F (2012) Chemokine CXCL12 and its receptors in the developing central nervous system: emerging themes and future perspectives. Dev Neurobiol 72:1349-1362. CrossRef Medline

Zhu Y, Matsumoto T, Mikami S, Nagasawa T, Murakami F (2009) SDF1/ CXCR4 signalling regulates two distinct processes of precerebellar neuronal migration and its depletion leads to abnormal pontine nuclei formation. Development 136:1919-1928. CrossRef Medline

Zujovic V, Thibaud J, Bachelin C, Vidal M, Coulpier F, Charnay P, Topilko P, Baron-Van Evercooren A (2010) Boundary cap cells are highly competitive for CNS remyelination: fast migration and efficient differentiation in PNS and CNS myelin-forming cells. Stem Cells 28:470-479. Medline

Zujovic V, Thibaud J, Bachelin C, Vidal M, Deboux C, Coulpier F, Stadler N, Charnay P, Topilko P, Baron-Van Evercooren A (2011) Boundary cap cells are peripheral nervous system stem cells that can be redirected into central nervous system lineages. Proc Natl Acad Sci U S A 108:1071410719. CrossRef Medline 